\title{
[Un]happy Together: Why the Supremacy Clause Preempts State Law Digital Performance Rights in Radio-Like Streaming of Pre-1972 Sound Recordings
}

\author{
Julie L. Ross
}

Georgetown University Law Center, rossj@law.georgetown.edu

This paper can be downloaded free of charge from:

https://scholarship.law.georgetown.edu/facpub/1478

http://ssrn.com/abstract=2595794

62 J. Copyright Soc'y U.S.A. 545 (Summer 2015)

This open-access article is brought to you by the Georgetown Law Library. Posted with permission of the author. Follow this and additional works at: https://scholarship.law.georgetown.edu/facpub 


\title{
[UN]HAPPY TOGETHER: WHY THE SUPREMACY CLAUSE PREEMPTS STATE LAW DIGITAL PUBLIC PERFORMANCE RIGHTS IN RADIO-LIKE STREAMING OF PRE-1972 SOUND RECORDINGS
}

\author{
by Julie L. Ross*
}

\section{INTRODUCTION}

Lovers of the music of Frank Sinatra, Elvis Presley, Etta James, and hundreds of other recording artists whose records were made before February 15,1972 , could soon have a hard time hearing those great artists on any satellite or Internet radio service. Recently, two federal district court opinions concluded that state laws were violated when satellite radio broadcaster Sirius XM Radio included pre-1972 sound recordings in its broadcasts without the owners' permission. ${ }^{1}$ Faced with potential liability under a patchwork of ambiguous and differing state common law claims, those engaged in the business of digitally streaming music to listeners over the Internet or via satellite radio may very well opt to remove pre-1972 recordings from their playlists, ${ }^{2}$ which would benefit neither the public nor the owners of these recordings.

*Professor Ross has been a member of the full-time faculty at Georgetown University Law Center since 1998, teaching courses in music law, entertainment law, legal writing and analysis, and transnational legal problem-solving. She is grateful to Jeffrey Shulman, Julie Cohen, and Bill Buzbee, among others (you know who you are!), for their advice and feedback on this article; to Barr Benyamin for his helpful work as research assistant; to Georgetown for its scholarship support; and to her family for their patience, without which this article could not have been written.

1 See Flo \& Eddie, Inc. v. Sirius XM Radio, Inc., 112 U.S.P.Q.2d 1307 (C.D. Cal. 2014); Flo \& Eddie, Inc. v. Sirius XM Radio, Inc., No. 13 Civ. 5784, 2014 WL 7172270 (S.D.N.Y. Nov. 14, 2014), leave to appeal granted, No. 15-1164 (2d Cir. Apr. 15, 2015). Although the reasoning of the courts in both decisions could potentially apply to terrestrial radio broadcasters as well as to those who digitally transmit sound recordings to their listeners, this article focuses solely on the digital performance right in sound recordings - and to exploitation of those rights through radio-like digital streaming - and not on any other potential performance rights that might be found to be protected under state law.

2 In Pandora's 2014 SEC filings, the company noted:

$[\mathrm{P}]$ rotection of sound recordings created prior to February 15, 1972 ("pre1972 sound recordings") remains governed by a patchwork of state statutory and common laws. Copyright owners of pre-1972 sound recordings have commenced litigation against us, alleging violations of New York and California state statutory and common laws with respect to the unau- 
When Congress first provided federal copyright protections to sound recordings in 1971, it limited the exclusive rights of sound recording owners to reproduction, distribution, and adaptation rights, and granted those rights prospectively only. ${ }^{3}$ No federal public performance right in sound recordings - e.g., the right to broadcast the recording to the public or to play it in a public place such as a bar, restaurant, or stadium - existed until 1995, when sound recordings were granted a limited digital public performance right that applies in the context of Internet and satellite streaming of music. ${ }^{4}$

All other public performances of sound recordings remain unprotected by the federal Copyright Act and have never been a source of revenue for owners of those sound recordings or the artists who created them. Thus, for example, although the author of a musical composition is compensated when a recording of the composition is played on a terrestrial radio station or at a sporting event, neither the copyright owners of the sound recording itself nor the artists who performed the musical work are

thorized reproduction and public performance of pre-1972 sound recordings, seeking, among other things, restitution, disgorgement of profits, and punitive damages as well as injunctive relief prohibiting further violation of those copyright owners' alleged exclusive rights. Litigation has been brought previously against Sirius XM Radio Inc. ("Sirius") for similar claims, and a federal district court and a state court in California recently ruled against Sirius for violating exclusive public performance rights in California. That same plaintiff has initiated litigation against us, alleging similar violations of exclusive rights under California law. If we are found liable for the violation of the exclusive rights of any pre-1972 sound recording copyright owners, then we could be subject to liability, the amount of which could be significant. If we are required to obtain licenses from individual sound recording copyright owners for the reproduction and public performance of pre-1972 sound recordings, then the time, effort and cost of securing such licenses directly from all owners of sound recording used on our service could be significant and could harm our business and operating results. If we are required to obtain licenses for pre-1972 sound recordings to avoid liability and are unable to secure such licenses, then we may have to remove pre-1972 sound recordings from our service, which could harm our ability to attract and retain users. Pandora Media Group, Inc., SEC Form 10Q at 39-40 (Sept. 30, 2014), available at http://services.corporate-ir.net/SEC.Enhanced/SecCapsule.aspx?c= $227956 \&$ fid $=9722252$.

3 An Act to amend title 17 of the United States Code to provide for the creation of a limited copyright in sound recordings for the purpose of protecting against unauthorized duplication and piracy of sound recording, and for other purposes, Pub. L. No. 92-140, § 1, 85 Stat. 391 (1971).

4 Digital Performance Right in Sound Recordings Act of 1995, Pub. L. No. 10439, § 2, 109 Stat. 336, 336 (codified at 17 U.S.C. § 106(6)). 


\begin{tabular}{lllll}
\hline |ljciprod01 $\mid$ productn $\backslash \mathrm{C} \backslash \mathrm{CPY} \backslash$ 62-4\CPY402.txt & unknown & Seq: 3 & 29-OCT-15 & 15:26 \\
\hline
\end{tabular}

required to be compensated under United States copyright law. This has been true since the dawn of the recording industry over a century ago. ${ }^{5}$

Sound recordings "fixed" prior to February 15, 1972, the effective date of the Sound Recording Act of 1971 ("1971 SRA"), 6 receive no federal copyright protection, so owners of pre-1972 sound recordings must instead look to state law for protection against unauthorized copying. Prior to enactment of the 1971 SRA, without any federal protection for sound recordings, the recording industry had been able to protect its interests, and thus to grow and flourish, by relying on state statutes and common law doctrines such as misappropriation and unfair competition to prevent others from copying and selling the records they produced. ${ }^{7}$ More than four decades ago, in 1973, the United States Supreme Court ruled that a California state criminal law protecting against unauthorized duplication of pre-1972 sound recordings was not preempted under the Supremacy Clause of the Constitution. ${ }^{8}$ In contrast to the decades-long protections offered by state law against unauthorized copying and distribution of sound recordings prior to 1971, however, no state statute and only one state court decision recognized any right by owners of sound recordings to protect their works against unauthorized public performances until very recently. ${ }^{9}$

5 The United States is one of only a few countries that has not recognized a full performance right in sound recordings. See generally U.S. CoPYRIGHT OFFice, Report on Copyright and the Music Marketplace 45 \& n.197 (Feb. 2015) [hereinafter Copyright And the Music Marketplace], available at http://copyright.gov/docs/musiclicensingstudy/copyright-andthe-music-marketplace.pdf (noting that "[o]nly a handful of countries - including Iran and North Korea - lack such a right, in addition to the United States").

6 An Act to amend title 17 of the United States Code to provide for the creation of a limited copyright in sound recordings for the purpose of protecting against unauthorized duplication and piracy of sound recording, and for other purposes, Pub. L. No. 92-140, § 3, 85 Stat. 391 (1971). As the Copyright Office has noted, "Why Congress did not incorporate pre-1972 recordings into the federal statute in 1976 is an interesting question, but neither the stakeholders nor the Copyright Office have an answer to it." U.S. CoPyright Office, Report on Federal Copyright Protection for Pre1972 Sound Recordings 121 (Dec. 2011) [hereinafter Federal CopyRight Protection for Pre-1972 Recordings], available at http:/copyright.gov/docs/sound/pre-72-report.pdf.

7 See generally Copyright Protection for Pre-1972 Sound Recordings, supra note 6 , at $20-49$.

8 Goldstein v. California, 412 U.S. 546 (1973).

9 That is, until recent litigation raised the issue in connection with digital streaming of pre-1972 sound recordings. See Section I(B), infra. 
\begin{tabular}{lllll}
\hline |ljciprod01 $\mid$ productn $\backslash \mathrm{C} \backslash \mathrm{CPY} \backslash$ 62-4\CPY402.txt & unknown & Seq: 4 & 29-OCT-15 & $15: 26$ \\
\hline
\end{tabular}

548

Journal, Copyright Society of the U.S.A.

Although Congress opted to exclude pre-1972 sound recordings from federal copyright protection when it passed the 1971 SRA, ${ }^{10}$ it recognized that owners of pre-1972 recordings relied on the existing patchwork of state laws to protect against record piracy. ${ }^{11}$ Thus, when it enacted $\S 301$, the preemption clause of the 1976 Copyright Act, ${ }^{12}$ Congress expressly exempted state laws governing pre-1972 sound recordings from preemption until February 15, 2067, when any remaining state law protection for pre-1972 sound recordings will finally be preempted. ${ }^{13}$ As a result, even though most of these state laws are more likely than not preempted with respect to any sound recordings fixed after February 15, 1972, ${ }^{14}$ they are still the only source of protection for owners of pre-1972 sound recordings against those who seek to make use of those works.

However, the fact that $\S 301$ 's express preemption clause does not apply to pre-1972 sound recordings until 2067 does not end the inquiry about whether a particular state law that purports to grant copyright-like rights to owners of pre-1972 sound recordings is preempted by federal law. In addition to any express preemption clause that Congress might incorporate into a statutory framework, the Supremacy Clause of the U.S. Constitution $^{15}$ requires that state law give way to federal law under specific circumstances, including when state laws conflict with federal law. ${ }^{16}$ This

10 Pub. L. No. 92-140, § 3, 85 Stat. 391 (1971).

11 See Federal Copyright Protection for Pre-1972 Sound Recordings, supra note 6 , at $10-17,47-49$.

1217 U.S.C. $\$ 301$ (2012).

13 Id. $\S 301(\mathrm{c})$.

14 I say "more likely than not" here because preemption under $\S 301$ is considered on a case-by-case basis, looking at the nature of the state law at issue and whether it addresses a work protected by federal copyright law and a use of that work that is equivalent to one of the exclusive rights granted to copyright owners under federal law. See generally 1 Melville B. Nimmer \& David Nimmer, Nimmer on Copyright § 1.01 (2015); Joseph P. Bauer, Addressing the Incoherency of the Preemption Provision of the Copyright Act of 1976, 10 VAND. J. ENT. \& TECH. L. 1, 3, 16-106 (2007) (summing up the body of case law analyzing preemption of state laws under $\S 301$ and stating "in the quarter-century-plus since the Act became effective in 1978, there have been literally hundreds of federal and state court decisions in which courts have been required to apply and interpret this statutory provision," $i d$. at 3). The application of $\S 301$ 's statutory preemption provision is outside the scope of this article, as it is acknowledged that $\S 301$ provides no defense for users of pre-1972 sound recordings against claims brought under state law.

15 U.S. CONST. art. VI, cl. 2.

16 See, e.g., Arizona v. United States, 132 S. Ct. 2492, 2501 (2012). The other circumstances in which Supremacy Clause preemption applies are those in which compliance with both federal and state law is impossible or where Congress has demonstrated an intent to displace state law by creating so 


\begin{tabular}{lllll}
\hline |ljciprod01 $\mid$ productn $\backslash \mathrm{C} \backslash \mathrm{CPY} \backslash$ 62-4\CPY402.txt & unknown & Seq: 5 & 29-OCT-15 & 15:26 \\
\hline
\end{tabular}

"conflict preemption" arises under the Supremacy Clause when a "challenged state law 'stands as an obstacle to the accomplishment and execution of the full purposes and objectives of Congress." "17

State laws purporting to grant public performance rights to pre-1972 sound recordings raise a thorny federalism issue - involving an express statutory preemption provision, a statutory saving clause, and the subsequent creation of a comprehensive federal licensing system - that must be addressed by any court considering whether to enforce those state laws. This article argues that where recognition and enforcement of state law property rights in public performances would interfere with the rights and obligations created by the Digital Performance Right in Sound Recordings Act of 1995 ("1995 DPRA"), those state law rights are necessarily preempted by the Supremacy Clause and are not saved by the saving clause. Enforcement of such state laws would create a serious obstacle to "the accomplishment and execution of the full purposes and objectives of Congress" in enacting the 1995 DPRA.

Part I provides an overview of federal protection for sound recordings. In addition, the (very) brief history of performance rights in sound recordings is discussed, noting the absence of any express state law recognition of a performance right in sound recordings and only minimal recognition of any rights analogous to performance rights during all of the twentieth century - in fact, some states enacted statutes expressly disclaiming the existence of such a right and others expressly exempted radio broadcasts from any criminal copyright infringement liability. Only recently, in the context of disputes over digital performances of pre-1972 sound recordings, has the issue of state protection of performance rights arisen in earnest, and the courts that have issued initial rulings about the validity of those state law claims did not consider Supremacy Clause preemption.

Part II explains the relevant legislative history and provisions of the 1995 DPRA. The 1995 DPRA established a complex and comprehensive compulsory licensing system that was in part designed to streamline the ability of digital radio services to have access to the body of available sound recordings upon payment of a statutory license fee, without the need for individual license agreements for each work. In creating the digital public performance right in sound recordings, Congress recognized that it was creating a right that had previously been denied to owners of sound recordings and thus defined that right narrowly. It also emphasized the

pervasive a framework of regulation that leaves no room for state action, $i d$., neither of which is argued to apply here.

17 Id. (quoting Hines v. Davidowitz, 312 U.S. 52, 67 (1941)). 


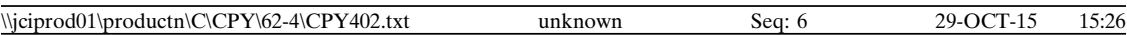

importance of the careful balancing of interests and the need for an easily administrable system of licensing.

Part III introduces Supremacy Clause preemption analysis and summarizes the Supreme Court's opinion in Goldstein v. California. ${ }^{18}$ In Goldstein, the Court acknowledged the applicability of Supremacy Clause preemption in the context of state laws that might conflict with the federal Copyright Act but found that the particular California statute at issue, which criminalized the physical copying and distribution of sound recordings without the owner's consent, was not preempted. The Supreme Court's reasoning in Goldstein and subsequent Supremacy Clause jurisprudence supports a different outcome in the context of at least some digital public performances of sound recordings. The Supremacy Clause preempts state laws purporting to require licenses for digital public performances of pre-1972 sound recordings by Internet or satellite radio stations beyond what is expressly provided for in the comprehensive and complex compulsory licensing system established by the 1995 DPRA because those laws serve as obstacles to the purposes of the federal statutory licensing system.

Part IV acknowledges that preemption of state law protection for digital public performances of pre-1972 sound recordings raises equitable concerns. Preemption leaves some of this nation's most treasured musical artists uncompensated for use of their works by Internet and satellite streaming services while the authors of more current works are compensated. However, it was Congress that created the framework for this inequity by leaving pre-1972 sound recordings unprotected by federal copyright law. Given the delicate balancing that has gone into Congress' recognition of a digital performance right in sound recordings and creation of a compulsory statutory licensing system, any remedy for the inequity to owners and authors of pre-1972 sound recordings must be left to Congress. Allowing individual courts in individual states to craft a patchwork of inconsistent remedies would disrupt the balance struck by Congress and interfere with the functioning of the compulsory license system for digital performances of sound recordings. This is a result that the Supremacy Clause does not permit.

18412 U.S. 546 (1973). 
\begin{tabular}{lllll}
\hline |ljciprod01 $\mid$ productn $\backslash \mathrm{C} \backslash \mathrm{CPY} \backslash$ 62-4\CPY402.txt & unknown & Seq: 7 & 29-OCT-15 & $15: 26$ \\
\hline
\end{tabular}

State Law Digital Public Performance Rights

I. DON'T PLAY THAT SONG: ${ }^{19}$ SOME RELEVANT FEDERAL COPYRIGHT BACKGROUND AND THE BRIEF HISTORY OF EFFORTS TO PROTECT PERFORMANCE RIGHTS IN SOUND RECORDINGS UNDER STATE LAW

To lay the foundation for the federal preemption issues raised by the application of state laws to Internet and satellite streaming of sound recordings, this section provides some background on federal copyright protections relating to sound recordings, discusses the history of state law protections for performances of sound recordings, and ends with a summary of the 2014 judicial decisions that have interpreted both California and New York state law to encompass public performance rights in sound recordings.

\section{A. A-B-C:20 Legal Protection (or Lack Thereof) of Sound Recordings Under Federal Law and the Genesis of the $\$ 301$ Express \\ Preemption and Saving Clauses}

Although sound recordings have existed since the invention of the phonograph in 1877 by Thomas Edison, ${ }^{21}$ United States copyright law was slow to recognize them as creative works deserving protection separate from the copyright granted in the underlying musical composition. Musical compositions (fixed in the form of musical notation) first received federal copyright protection in $1831,{ }^{22}$ but sound recordings did not receive federal copyright protection until 140 years later, with the enactment of the 1971 SRA. ${ }^{23}$ States were thus free for many decades to legislate regarding or to apply common law protections to recorded works without coming into conflict with federal copyright law. ${ }^{24}$ Those protections, how-

19 Composed by Ahmet Ertegun and Betty Nelson, first recorded by Ben E. King in 1962 and then by Aretha Franklin in 1970.

20 Composed by The Corporation (Berry Gordy, Freddie Perren, Alphonzo Mizell, and Deke Richards), recorded and released by The Jackson 5 in 1970.

21 Russell Sanjek, Pennies from Heaven: The American Popular Music Business in the Twentieth Century, at vi-vii (1996).

22 An Act to Amend the Several Acts Respecting Copyrights, ch. 16, §§ 1-3, 4 Stat. 436 (1831), reprinted in United States Copyright Office, CopyRight Enactments: Laws Passed in the United States Since 1783 ReLating to Copyright, Bulletin No. 3 (rev. ed. 1973), available at http:// copyright.gov/history/Copyright_Enactments_1783-1973.pdf.

23 An Act to amend title 17 of the United States Code to provide for the creation of a limited copyright in sound recordings for the purpose of protecting against unauthorized duplication and piracy of sound recordings, and for other purposes, Pub. L. No. 92-140, § 1, 85 Stat. 391 (1971).

24 See Gary Pulsinelli, Happy Together? The Uneasy Coexistence of Federal and State Protections for Sound Recordings, 82 TEnN. L. REv. 167, 172 (2014) 


\begin{tabular}{lllll}
\hline |ljciprod01 $\mid$ productn $\backslash \mathrm{C} \backslash \mathrm{CPY} \backslash$ 62-4\CPY402.txt & unknown & Seq: 8 & 29-OCT-15 & $15: 26$ \\
\hline
\end{tabular}

ever, were largely focused on preventing piracy - the unauthorized reproduction of the recordings and sale of those recordings to the public. ${ }^{25}$

Federal copyright in any given work provides a specified "bundle" of exclusive rights in that work. Although every copyrighted work is protected from unauthorized reproduction, distribution, and preparation of derivative works, only some copyrighted works are protected against unauthorized public performances of the work. ${ }^{26}$ Federal copyright law provided no protection for sound recordings until February 15, 1972, the effective date of the 1971 SRA, but the 1971 SRA limited the exclusive rights in sound recordings solely to reproduction, distribution, and adaptation (i.e., the creation of "derivative works" based on the sound recording). ${ }^{27}$ Owners of sound recordings that were fixed after February 15, 1972 were not granted a federal "public performance" right by the 1971 SRA, despite the fact that such a right was granted for virtually all other categories of works protected by federal copyright. ${ }^{28}$ Thus, radio stations were free to broadcast and public venues such as bars and stadiums were free to play recorded music without seeking permission from or compensating sound recording owners and performers. In fact, they have done so for decades, and the broadcast industry in particular built its business model around the uncompensated public performances of sound recordings, with sound recording owners presumably benefitting from the promotion of their recordings on the public airwaves. ${ }^{29}$

(discussing the "dual state/federal protection scheme" adopted under the 1909 Copyright Act).

25 See generally Barbara Ringer, The Unauthorized Duplication of Sound Recordings 2-20 (Comm. Print 1957) (General Revision of the Copyright Law, Study No. 26, Senate Subcomm. on the Judiciary), available at http://www.copyright.gov/history/studies/study26.pdf (providing detailed history of efforts to provide federal copyright protection for sound recordings and summarizing state law protections against duplication and distribution of sound recordings, stating at 11 " [t] hese laws consist almost entirely of judge-made common law ... [,] differ widely from State to State, and are often conflicting and irreconcilable").

2617 U.S.C. $\$ 106$ (2012).

27 An Act to amend title 17 of the United States Code to provide for the creation of a limited copyright in sound recordings for the purpose of protecting against unauthorized duplication and piracy of sound recording, and for other purposes, Pub. L. No. 92-140, § 1, 85 Stat. 391 (1971).

28 Id. $\S(\mathrm{a})$.

29 See generally COPYRIGHT AND THE Music MARKetPlace, supra note 5, at 44 ("In the traditional view of the market, broadcasters and labels representing copyright owners enjoy a mutually beneficial relationship whereby terrestrial radio stations exploit sound recordings to attract the listener pools that generate advertising dollars, and, in return, sound recording owners receive exposure that promotes record and other sales."). 


\begin{tabular}{lllll}
\hline |ljciprod01 $\mid$ productn $\backslash \mathrm{C} \backslash \mathrm{CPY} \backslash$ 62-4\CPY402.txt & unknown & Seq: 9 & 29-OCT-15 & 15:26 \\
\hline
\end{tabular}

The Register of Copyright had advocated for a performance right in sound recordings, ${ }^{30}$ but consideration of the competing interests was deferred in contemplation of the comprehensive copyright revision process that led to the Copyright Act of $1976,{ }^{31}$ which again deferred consideration of the issue by requesting a Copyright Office report on granting a performance right in sound recordings. That report, issued in 1978 (the "Ringer Report"), recommended that a full performance right be granted to sound recordings, ${ }^{32}$ a position that the Copyright Office has advocated ever since and that Congress has consistently refused to adopt. ${ }^{33}$

When the federal Copyright Act was revised in 1976, Congress expressed a strong interest in national uniformity in copyright laws and incorporated an express preemption provision into the Act. ${ }^{34}$ Because the 1971 SRA applied only prospectively, sound recordings that had been fixed (i.e., recorded) prior to the effective date of the Act have never been afforded federal copyright protection. Section 301's preemption language thus also included a saving clause, recognizing that pre-1972 sound recordings would be without any legal protection at all if they remained unpro-

30 U.S. Copyright Office, Performance Rights in Sound Recordings 3-7 (Comm. Print 1978) [hereinafter RINGER REPORT].

31 Copyright Act of 1976, Pub. L. No. 94-553, 90 Stat. 2541 (provision on limitations on the exclusive right codified at 17 U.S.C. $\$ 114(\mathrm{~d})$ ).

32 Ringer REPORT, supra note 30, at 3-7.

33 See S. Rep. No. 104-128, at 13 (1995) (recognizing that the Copyright Office had advocated for a comprehensive performance right in sound recordings but instead adopting a narrowly-tailored digital performance right to balance the competing interests at stake).

3417 U.S.C. § 301(a) (2012); see S. REP. No. 94-473, at 115 (1975) ("The preemption of rights under State law is complete with respect to any work coming within the scope of the bill, even though the scope of exclusive rights given the work under the bill is narrower than the scope of common law rights in the work might have been."); H. REP. No. 94-1476, at 131 (1975) ("regardless of when the work was created and whether it is published or unpublished, disseminated or undisseminated, in the public domain or copyrighted under the Federal statute, the States cannot offer it protection equivalent to copyright"). As stated in the House Report, § 301 was "one of the bedrock provisions of the bill" that would:

accomplish a fundamental and significant change in the present law. Instead of a dual system of "common law copyright" for unpublished works and statutory copyright for published works, which has been the system in effect in the United States since the first copyright statute in 1790, the bill adopts a single system of Federal statutory protection from creation. ... By substituting a single Federal system for the present anachronistic, uncertain, impractical, and highly complicated dual system, the bill would greatly improve the operation of the copyright law and would be much more effective in carrying out the basic constitutional aims of uniformity and the promotion of writing and scholarship.

H. ReP. No. 94-1476, at 129. 


\begin{tabular}{lllll}
\hline |ljciprod01 $\mid$ productn $\backslash \mathrm{C} \backslash \mathrm{CPY} \backslash$ 62-4\CPY402.txt & unknown & Seq: 10 & 29-OCT-15 & 15:26 \\
\hline
\end{tabular}

tected by federal law and if all state laws providing copyright-like protection were preempted. ${ }^{35}$ The $\S 301(\mathrm{c})$ saving clause states in pertinent part:

(c) With respect to sound recordings fixed before February 15, 1972, any rights or remedies under the common law or statutes of any State shall not be annulled or limited by this title until February 15, 2067. The preemptive provisions of subsection (a) shall apply to any such rights and remedies pertaining to any cause of action arising from undertakings commenced on and after February 15, 2067.

The legislative history of the saving clause shows that it was intended to allow continued protection for pre-1972 sound recordings against record piracy - that is, the unauthorized reproduction and sale of records. The House Report explains the purpose of what became $\S 301$ (c) as follows:

A unique and difficult problem is presented with respect to the status of sound recordings fixed before February [15], 1972, the effective date of the amendment bringing recordings fixed after that date under Federal copyright protection. In its testimony during the 1975 hearings, the Department of Justice pointed out that, under $\S 301$ [the express preemption of state law claims equivalent to copyright with no savings clause] as written:

This language could be read as abrogating the anti-piracy laws now existing in 29 states relating to pre-February 15, 1972, sound recordings on the grounds that these statutes proscribe activities violating rights equivalent to ... the exclusive rights within the general scope of copyright. ... Certainly such a result cannot have been intended for it would likely effect the immediate resurgence of piracy of preFebruary 15, 1972 recordings. ... .

The result of the Senate amendment would be to leave pre-1972 recordings entitled to perpetual protection under State law, while post-1972 recordings would eventually fall into the public domain as provided in the bill.

The Committee recognizes that, under recent court decisions, pre-1972 recordings are protected by State statute or common law, and that should not all be thrown into the public domain instantly upon the coming into effect of the new law. However, it cannot agree that they should in effect be accorded perpetual protection, as under the Senate amendment, and it

3517 U.S.C. § 301(c) (2012); see H. Rep. No. 94-1476, at 133 (1975) (noting the concerns expressed by the Department of Justice that, without a saving clause, the preemption language of $\S 301$, "could be read as abrogating the anti-piracy laws now existing in 29 states relating to pre-February 15, 1972, sound recordings" and stating that "[c]ertainly such a result cannot have been intended for it would likely effect the immediate resurgence of piracy of pre-February 15, 1972 sound recordings"); S. REP. No. 94-473, at 116 (1975) (stating that the saving clause in what became § 301(c) "was proposed by the Department of Justice to clarify the intent of this title" and that "Congress and many states have determined that record pirates unfairly appropriate the property, efforts, and capital of the legitimate music industry"). 


\begin{tabular}{lllll}
\hline |ljciprod01 $\backslash$ productn $\backslash \mathrm{C} \backslash \mathrm{CPY} \backslash 62-4 \backslash \mathrm{CPY} 402 . t x t$ & unknown & Seq: 11 & 29-OCT-15 & 15:26 \\
\hline
\end{tabular}

has therefore revised [§ 301(c)] to establish a future date for the pre-emption to take effect. ${ }^{36}$

As the Senate Report stated:

The addition of $[\$ 301(\mathrm{c})]$ to the bill was proposed by the Department of Justice to clarify the intent of this title. At the present time, 32 states prohibit record piracy by statute, and four more do so under common law. The Congress and many states have determined that record pirates unfairly appropriate the property, efforts and capital of the legitimate music industry. There is no justification for exposing pre-1972 recordings to expropriation by record pirates. ${ }^{37}$

Thus, the saving clause in $\S 301$ (c) was intended to preserve state law protections against record piracy. At the time that Congress enacted the saving clause, its focus was on retaining existing state law protections against duplication and sale of pre-1972 recordings. It did not contemplate that state laws would be invoked to prohibit public performances of sound recordings, and the possibility of a future recognition of a federal performance right in sound recordings was still uncertain.

\section{B. Long Ago (And Far Away): ${ }^{38}$ Early Cases Relating to Broadcasts of Sound Recordings}

Although there is a long history of state law protection against reproduction and distribution of sound recordings dating back almost to the birth of the recording industry in the early decades of the twentieth century, ${ }^{39}$ there is little evidence of any state law recognition of a performance right in sound recordings prior to $2014 . .^{40}$ In fact, during the years

36 H. Rep. No. 94-1476, at 133 (1975).

37 S. REP. No. 94-473, at 116 (1975).

38 Composed by Ira Gershwin and Jerome Kern, recorded by Frank Sinatra in 1944.

39 See Bauer, supra note 14, at 16-106.

40 As will be discussed in Section I(C) infra, in 2014, opinions addressing state law performance rights were issued by two separate federal district court cases involving claims brought against Sirius XM Radio under California and New York law by members of The Turtles for alleged violations of the digital performance right in their pre-1972 recordings over Sirius XM's satellite radio service. See Flo \& Eddie, Inc. v. Sirius XM Radio, Inc., 112 U.S.P.Q.2d 1307 (C.D. Cal. 2014); Flo \& Eddie, Inc. v. Sirius XM Radio, Inc., No. 13 Civ. 5784, 2014 WL 7172270 (S.D.N.Y. Nov. 14, 2014). As of the writing of this article, the question of whether Florida law provides similar state law protections of performance rights had just been decided in the negative by the Southern District of Florida. See Flo \& Eddie, Inc. v. Sirius XM Radio, Inc., Case No. 1:13-CV-23182, Order Granting Defendant Sirius XM's Motion for Summary Judgment on Liability (S.D. Fla. June 22, 2015). The district court decision is now being appealed. See Flo \& Eddie, Inc. v. Sirius XM Radio, Inc., No. 15-13100 (11th Cir. notice of appeal July 10, 2015). 
\begin{tabular}{lllll}
\hline |ljciprod01 $\mid$ productn $\backslash \mathrm{C} \backslash \mathrm{CPY} \backslash$ 62-4\CPY402.txt & unknown & Seq: 12 & 29-OCT-15 & 15:26 \\
\hline
\end{tabular}

between 1941 and 2014 when radio stations were regularly broadcasting sound recordings, state laws were not invoked to prevent radio stations from doing so despite the absence of a license and failure to pay any compensation to the sound recording owners or performers. During those years, owners of sound recordings and artists who performed on them repeatedly sought relief from Congress in the form of federal protection for sound recordings that included a performance right, arguing the inequity of free use of their recordings by the broadcast industry. ${ }^{41}$ The few cases that were brought to challenge the radio broadcast of sound recordings did not assert a right to control the performance of the work per se; instead they were based on written notices placed on sound recordings that purported to limit their use by the purchasers or the unfair competition resulting when live radio broadcasts of performances by musicians were competing with unauthorized broadcasts of recorded performances by the same musicians. ${ }^{42}$

The closest thing to recognition of a performance right in sound recordings under state law before the 1976 Copyright Law and 1995 DPRA were enacted was the Pennsylvania Supreme Court's opinion in Waring $v$. WDAS Broadcasting Station, ${ }^{43}$ decided in 1937 after orchestra leader Fred Waring sued a Pennsylvania radio station for playing one of his records over the air in spite of a statement on the label of the record reading "Not licensed for radio broadcast." 44 The use of "not for radio broadcast" and

41 Ringer RePORT, supra note 30, at 28-58. In addition, music publishers and composers were actively engaged in enforcing the performance right in compositions against radio broadcasters during this time frame. Although there were many legal skirmishes that resulted in ongoing antitrust consent decree oversight of radio broadcasters' obligations to obtain a license and pay royalties to composition owners, broadcasters have paid performance royalties to the owners of the musical compositions that were performed on sound recordings since as early as the 1920 s. See Bernard Korman, U.S. Position on Collective Administration of Copyright and Anti-Trust Law, $43 \mathrm{~J}$. Copyright Soc'y 158 (1995); RINGER RePORT, supra note 30, at 28-58. Similarly, although the focus of this article is on radio and radio-like services, it should be noted that musical composers were actively enforcing their federal performance right in lawsuits through blanket license negotiations with hotels, theaters, and arenas from at least as early at 1915 , but recording artists or labels did not pursue state law remedies when the same sorts of venues began regularly performing sound recordings at events hosted in their facilities. See generally Russell SAnjer, Pennies from Heaven: The American Popular Music Business in the Twentieth Century (1996).

42 See Waring v. WDAS Broad. Station, Inc., 194 A. 631 (Pa. 1937); RCA Mfg. Co. v. Whiteman, 114 F.2d 86 (S.D.N.Y. 1940), cert. denied, 311 U.S. 712 (1940); Waring v. Dunlea, 26 F. Supp. 338 (E.D. N.C. 1939).

43194 A. 631 (Pa. 1937).

44 Id. 


\begin{tabular}{lllll}
\hline |ljciprod01 $\mid$ productn $\backslash \mathrm{C} \backslash \mathrm{CPY} \backslash$ 62-4\CPY402.txt & unknown & Seq: 13 & 29-OCT-15 & 15:26 \\
\hline
\end{tabular}

similar labels in the late 1930s was described by Prof. Robert Gorman as an effort by the American Federation of Musicians ("AFM") to protect union jobs for live musicians in radio broadcasts and enforce a requirement of union contracts with record labels. ${ }^{45}$ In affirming the grant of an injunction against further broadcasts of Waring's recordings, the Pennsylvania Supreme Court first found that there can be a common law property right in the performances of "those artists who elevate interpretations to the realm of independent works of art" and that Waring's orchestra met that standard because of its international acclaim and evidence that it was "unique" in its artistry. ${ }^{46}$ The Pennsylvania Supreme Court then concluded that the restrictive covenant on the sale of the records, prohibiting broadcast of the recording over the radio, was not a violation of public policy and could be enforced in equity. ${ }^{47}$ The court found that the doctrine of unfair competition also supported the injunction, because the orchestra typically was paid $\$ 13,500$ for a single live performance over the radio and the defendant radio station, for the 75-cent cost of a record, had "appropriate[d] and utilize[d] for its own profit the musical genius and artistry of plaintiff's orchestra in commercial competition with the orchestra itself." 48

In 1939, Waring similarly succeeded in enjoining a North Carolina radio station from using electrical transcriptions of his orchestra's performances that had been created for broadcast on the Ford Motor Program. ${ }^{49}$ The transcriptions were labeled with notices stating that the recording was only to be used by a specified distributee and solely for the purpose of being played on the Ford Motor Program. ${ }^{50}$ The court found that Waring's rendition of the composition created a property interest that could be subject to reasonable restrictive uses. It also found that the restrictions were reasonable because of the value of the performances and Waring's right to decide whether, when, how, and for whose advantage the renditions would be "mechanically reproduced." 51

45 Robert A. Gorman, The Recording Musician and Union Power: A Case Study of the American Federation of Musicians, 37 Sw. L.J. 697, 704 (1983).

46 Waring, 194 A. at 635.

47 Id. at $447-48$.

48 Id. at $454,455-56$.

49 Waring v. Dunlea, 26 F. Supp. 338 (E.D. N.C. 1939). Electrical transcriptions are sound recordings that are (or were, in the early days of radio) specifically made for radio broadcast.

$50 \mathrm{Id}$. at 339.

51 Id. at $339-40$. 
However, in spite of scholarly comment favoring the result in Waring, 52 subsequent events made these successes short-lived. The North Carolina legislature almost immediately enacted legislation specifically aimed at overruling the Waring $v$. Dunlea decision, expressly providing that any common law right to limit uses of a sound recording expires upon sale of the recording. ${ }^{53}$ South Carolina enacted a similar statute around the same time. ${ }^{54}$ Ultimately, over the next several decades, statutes were passed in almost every state in the U.S., limiting the ability of performers or owners of sound recordings to seek relief under state criminal law for radio broadcasts of sound recordings of those performances. ${ }^{55}$

52 See Note, Rights of Performers and Recorders Against Unlicensed Record Broadcasts, 49 YAle L.J. 559, 560 n.6 (1940) (citing a series of scholarly articles in 1937 and 1938 that approved of the result in Waring).

53 N.C. Gen. STAT. $\$ 66-28$ (2014) (enacted in 1939 and providing that once a copy of a sound recording is sold in commerce, all common law rights that might attach to the recording are passed to the purchaser and any right to restrict the use of the recording is abrogated); Liberty/UA, Inc. v. Eastern Tape Corp., 180 S.E.2d 414, 418 (N.C. Ct. App. 1971) (noting legislative history of N.C. Gen. Stat. $\S 66-28$ and finding that the purpose of the statute was "to overrule the Waring decision by eliminating any common law right to restrict the use of a recording sold for use in this State," but that the statute was not intended to preclude claims based on unauthorized copying of records sold to the public).

54 Liberty/UA, Inc., 180 S.E.2d at 418 (citing S.C. Code Ann. § 39-3-510 (2011)) (originally enacted in 1942).

55 See Alaska Stat. § 45-50-900(b) (enacted in 1974, formerly § 45.51.010-.020); Arizona Rev. Stat. Ann. § 13-3705(B) (enacted in 1971 as $\$ 13-1024)$; Ark. Code Ann. \$ 5-37-510(d) (enacted in 1947 as $\$ 41-2375$ to -2376 ); Cal. Pen. Code $\$ 653 \mathrm{~h}(\mathrm{~g})$ (enacted in 1968); Colo. Rev. Stat. § 18-4-605 (enacted in 1976); Conn. Gen. Stat. Ann. \$ 53-142b(c) (enacted in 1974); Del. Code Ann. tit. 11, § 923 (enacted in 1976); D.C. Code Ann. § 223214(c)(2) (enacted in 1982); FLA. StAT. $\$ 540.11(6)$ (a) (enacted in 1971, formerly \$ 543.041); GA. CODE ANN. \$§16-8-60(c)(1) \& (2) (enacted in 1975); Haw. Rev. Stat. § 482C-4 (enacted in 1975); IDAHO CODE § 18-7606 (enacted in 1976); 720 Ill. Comp. Stat. 5/16-7(g) (enacted in 1961); Ind. Code $\$ \S 35-17-7-1$ to 3 (repealed by Pub. L. 148, § 24 (1976)); Iowa Code $\S 714-15$ (4) (enacted in 1977); Kan. Stat. Ann. § 21-3748(c) (enacted in 1976, repealed by Laws 2010, ch. 136, § 307, eff. July 1, 2011); Ky. Rev. Stat. § 434.445(5) (enacted in 1974); La. Rev. Stat. AnN. § 14.223.2 (enacted in 1972); Me. Rev. Stat. Ann. § 1261(5) (enacted in 1975); Mass. Gen. Laws Ann. §143D (enacted in 1990); Мich. Comp. Laws Ann. $\S 752.785$ (enacted in 1975); Minn. Stat. § 325E.19 (enacted in 1973); Miss. Code Ann. \& 97-23-91 (enacted in 1974); Mo. Ann. Stat. \& 570.245(1) (enacted in 1977, repealed by L. 2014, S.B. No. 491, § A, effective Jan. 1, 2017); Mont. Code Ann. § 30-13-146(2) (enacted in 1977 as § 85-606 of the Revised Code of Montana 1947); Neb. Rev. Stat. § 28-1325(1) (enacted in 1977); Nev. Rev. Stat. AnN. § 205.217(3) (enacted in 1973); N.H. Rev. STAT. §§ 352-A:2(III)(b)(1) \& (3) (enacted in 1973); N.J. STAt. § 2C:21- 


\begin{tabular}{lllll}
\hline |ljciprod01 $\backslash$ productn $\backslash \mathrm{C} \backslash \mathrm{CPY} \backslash 62-4 \backslash \mathrm{CPY} 402 . t x t$ & unknown & Seq: 15 & 29-OCT-15 & 15:26 \\
\hline
\end{tabular}

In RCA, Inc. v. Whiteman, 56 only three years after Waring was decided, the Second Circuit Court of Appeals acknowledged the Pennsylvania Supreme Court's decision but refused to issue an injunction in comparable circumstances under New York law. In Whiteman, an orchestra leader sought to restrain radio broadcasts of sound recordings of the orchestra's performances where the records bore a notice stating that the recording was "not licensed for radio broadcast" or "only for non-commercial use on phonographs in homes." 57 In spite of these notices, the defendant purchased records and broadcast them over its radio system. ${ }^{58}$ Judge Learned Hand, writing for the Second Circuit, noted that although recordings of performances of popular artists are "exceedingly valuable," neither the artists nor the maker of the records could "impose valid restrictions on their resale." 59 Judge Hand also questioned whether any right to control performances of a sound recording existed under common law copyright, stating,

Copyright in any form, whether statutory or at common-law, is a monopoly; it consists only in the power to prevent others from reproducing the copyrighted work. W.B.O. Broadcasting has never invaded any such

21(f)(1) (enacted in 1991); N.M. STAT. AnN. § 30-16B-6(A) (enacted in 1974); N.Y. Penal Law $§ 275.45(1)$ (a) (enacted in 1978 as $§ 275.25$ ); N.C. Gen. Stat. § 14-433(c) (enacted in 1973); N.D. Cent. Code § 47-21.1.05 (enacted in 1977); Ohio Rev. Code AnN. § 1333.52(C)(1)-(2) (enacted in 1976); 21 OKL. STAT. AnN. $\S 1865-1869$ (enacted in 1975, repealed by Laws 1991, c. 82, § 8); Or. Rev. Stat. §§ 164.873(2)(a)-(c) (enacted in 1993); 18 Pa. Comp. Stat. Ann. \$ 4116(c)(1)-(c)(2) (enacted in 1972); R.I. Gen. Laws 1956 § 6-13.1-15(d) (enacted in 1976); S.C. Code Ann. § 16-11-950 (enacted in 1975); S.D. Codified Laws AnN. § 43-43A-4(1) (enacted in 1975); Utah Code Ann. \$13-10-5(1) (enacted in 1973); VA. Code Ann. $\S 59.1-41.2$ (enacted in 1972); WASH. REv. CODE $§ 19-25-800$ (enacted in 1991); W. VA. Code $\$ 61-3-50(d)(5)$ (enacted in 1976); Wisc. Stat. § 943.207(4)(a) (enacted in 1975); Wyo. STAt. Ann. § 40-13-206(a)(i) (enacted in 1978).

56114 F.2d 86 (2d Cir. 1940), cert. denied, 311 U.S. 712 (1940).

57 Id. at 87.

$58 I d$.

59 Id . at 88. The court went on to conclude that the common law property interest in the performances "ended with the sale of the records and that the restriction did not save it; and that if it did, the records themselves could not be clogged with a servitude." Id. The determination that the sale of the records constituted a "publication" of the work that deprived it of common law copyright protection was later narrowed, if not overruled, to make it clear that the sale of records of a performance does not deprive the sound recording's owner of common law claims against those who copy and sell those records for profit. See Metro. Opera Ass'n v. Wagner-Nichols Recorder Corp., 101 N.Y.S.2d 483, 494-95 (Sup. Ct. N.Y. Cnty. 1950); Capitol Records, Inc. v. Mercury Records Corp., 221 F.2d 657, 663 (2d Cir. 1955); Capital Records, Inc. v. Naxos of Am., 830 N.E.2d 250 (N.Y. 2005). 


\begin{tabular}{lllll}
\hline |ljciprod01 $\mid$ productn $\backslash \mathrm{C} \backslash \mathrm{CPY} \backslash$ 62-4\CPY402.txt & unknown & Seq: 16 & 29-OCT-15 & 15:26 \\
\hline
\end{tabular}

right of Whiteman; they have never copied his performances at all; they have merely used those copies which he and the RCA Manufacturing Company, Inc. made and distributed. ${ }^{60}$

Acknowledging that the Supreme Court of Pennsylvania had reached a different conclusion in Waring, Judge Hand, "with much regret," indicated that the Second Circuit was unconvinced by the reasoning in Waring. ${ }^{61}$ Even though broadcasts by the defendant in Whiteman could reach Pennsylvania, where the performances of the plaintiff's recordings might constitute a tort, Judge Hand found that an injunction could not be confined to broadcasting to radio sets in Pennsylvania alone. ${ }^{62}$

Judge Hand also rejected unfair competition as a basis for relief, finding that without common law copyright protection for the recordings, there was no justification for allowing Whiteman and the record manufacturing company to have any control over how the public used the recording. Writing for the Second Circuit, he stated:

We cannot know how Congress would solve this issue; we can guess and our guess is that it would refuse relief as we are refusing it - but if our guess were the opposite, we should have no right to enforce it. If the talents of conductors and orchestras are denied that compensation which is necessary to evoke their efforts because they get too little for phonographic records, we have no means of knowing it, or any right to assume it; and it is idle to invoke the deus ex machina of a "progress" which is probably spurious, and would not be for us to realize, if it were genuine. ${ }^{63}$

The United States Supreme Court denied certiorari in the Whiteman case, after which no other reported decisions reflect any efforts by owners of or performers in sound recordings to bring state law-based challenges to radio broadcasts of those sound recordings. As Prof. Gorman describes it, "The impact of [Whiteman] was great, both because it was expressed in a most thoughtful opinion by the most highly regarded jurist of his day, Learned Hand, and because the Second Circuit encompassed New York, a center for record production and sales and for radio broadcasting." 64

After losing the battle in Whiteman, the AFM moved on to different tactics in seeking to prevent the broadcast of sound recordings or electrical transcriptions in lieu of live performances by musicians, including several

60114 F.2d at 88.

61 Id. at 89 (citing Waring v. WDAS Broad. Station, 194 A. 631 (Pa. 1937).

$62 \mathrm{Id}$. at 89-90. "We must therefore choose between denying any injunction whatever - since in our judgment the act is unlawful only in Pennsylvania - or enjoining W.B.O. Broadcasting Corporation from broadcasting throughout the Union and in Canada in order to prevent a tort in Pennsylvania alone. This would be an obvious misuse of the writ which goes only in aid of justice." Id.

$63 \mathrm{Id}$. at 90.

64 Gorman, supra note 45, at 704 . 


\begin{tabular}{lllll}
\hline |ljciprod01 $\mid$ productn $\backslash \mathrm{C} \backslash \mathrm{CPY} \backslash$ 62-4\CPY402.txt & unknown & Seq: 17 & 29-OCT-15 & 15:26 \\
\hline
\end{tabular}

multi-year strikes by union musicians. ${ }^{65}$ In response to those strikes and related efforts by the AFM that were viewed by many as strong-arm tactics, broadcasters successfully lobbied for federal legislation. ${ }^{66}$ "Attempts to impose direct pressure on the broadcasters were totally undermined by the Lea Act of 1946, which outlawed strikes — and thus effective collective bargaining - designed to expand or preserve live employment in radio, to eliminate or restrict the use of records in broadcasting, or even to extract performance royalties for the recording musicians for the radio use of their recordings. The failure to pressure the broadcasters on the issue of 'performers' rights' was attributable just as much to congressional mandate as to the preferences of Mr. Petrillo [the head of the AFM]."67 The Lea Act - part of the Telecommunications Act governing radio broadcasting — was principally aimed at barring strikes in support of efforts by musicians to impose limits on uses of recordings in radio broadcasts, such as the "not for radio broadcast" labels at issue in the Waring and Whiteman cases, or efforts to pressure broadcasters to pay musicians when electrical transcriptions of performances were rebroadcast. ${ }^{68}$

By the time the Copyright Act of 1976 was enacted, it was well known to Congress and to all participants in the music industry that radio stations had been performing sound recordings in their broadcasts without seeking permission from or paying the owners of the master recordings or performers on the recordings. If state law-based performance rights existed at all, they were dormant across the nation for the decades leading up to the 1971 SRA and the Copyright Act of $1976 .{ }^{69}$

65 See generally id. at 704-21.

66 Id. at $711-21$.

67 Id. at 784-85.

68 An Act to amend Title V of the Communications Act of 1934 so as to prohibit certain coercive practices affecting radio broadcasting, ch. 138, 60 Stat. 89 (1946) (codified at 47 U.S.C. § 506) (repealed by An Act to Appeal Section 506 of the Communications Act of 1934, Pub. L. No. 96-507, § 1, 94 Stat. 2747 (Dec. 8, 1980)); see also Gorman, supra note 45, at 717. Because the Lea Act was not repealed until 1980, its provisions precluding musicians or their representatives from using "duress" or "other means" to prevent radio broadcast of recordings remained in effect from 1946 through and beyond the effective date of the Copyright Act of 1976. For a detailed discussion of the Lea Act in relation to efforts of the American Federation of Musicians to protect musicians against radio broadcast of recorded performances, see Gorman, supra note 45.

69 See Copyright Protection for Pre-1972 Sound Recordings, supra note 6, at 44-45; Dorothy M. Schrader, Sound Recordings: Protection Under State Law and Under the Recent Amendment to the Copyright Code, 14 ArIz. L. REv. 689, 693 \& n.49 (1972) (describing state law protections for sound recordings fixed before the 1971 SRA became effective and hypothesizing that "there have been no cases on broadcasting of records since Whiteman because of altered industry practice and technological changes," with the 
\begin{tabular}{lllll}
\hline |ljciprod01 $\mid$ productn $\backslash \mathrm{C} \backslash \mathrm{CPY} \backslash$ 62-4\CPY402.txt & unknown & Seq: 18 & 29-OCT-15 & 15:26 \\
\hline
\end{tabular}

562

Journal, Copyright Society of the U.S.A.

Thus, when Congress opted to exclude pre-1972 sound recordings from federal protection and left them to the states to protect, there is no evidence of any intent by Congress to allow states to recognize and protect a performance right in sound recordings. The debate over whether to grant performance rights to sound recordings, which continued through the issuance of the Ringer Report in 1978 (and continues today), reflects the presumption of all interested parties that no such right existed. ${ }^{70}$ As will be discussed infra in Section II(B), the prospect of state laws applying to performance rights in pre-1972 sound recordings was also not mentioned or considered in the legislative history of the 1995 DPRA; by that point in time, all members of the music industry took it for granted that the only protection for performances of sound recordings was the limited digital public performance right granted for the first time in the 1995 DPRA. Thus, the music industry was floored when a series of decisions were issued by courts in the fall of 2014 that recognized the existence of state law protections for public performances of sound recordings. ${ }^{71}$

\section{B. Everybody Has the Right to Be Wrong (At Least Once): ${ }^{72}$ Recent Cases Addressing State Law Performance Rights \\ in Sound Recordings}

In practice, for many decades, state laws have presented no obstacle for radio broadcasts of sound recordings - which constitute performances of those recordings - and it is only recently that owners of pre-1972 sound recordings have begun to assert that a digital public performance right exists under state laws protecting sound recordings from unauthorized reproductions. In 2013, two decades after satellite radio companies first began digitally performing sound recordings over their services, the first of several related lawsuits were filed by owners of pre-1972 record-

decline of "live" radio performances by musicians making unfair competition claims inapplicable).

70 Ringer Report, supra note 30; see also Note, Performers' Rights and Copyright: The Protection of Sound Recordings from Modern Pirates, 59 CAL. L. REv. 548, 573 (1971) (describing the 1967 Senate subcommittee hearings on the copyright revision and "a rather massive effort" by interested parties to include a performance right in sound recordings, who argued that "the commercial value of a musical composition is created largely by the record manufacturer and the performing artists, who get no compensation from the use of their records by radio stations and other users").

71 See, e.g., Stephen Carlisle, Flo and Eddie v. Sirius XM Radio: Have Two Hippies from the 60's Just Changed the Course of Broadcast Music? (Oct. 2, 2014), http://copyright.nova.edu/flo-and-eddie-v-sirius-xm-radio.

72 Composed by Sammy Cahn and Jimmy Van Heusen, recorded by Frank Sinatra in 1965. 


\begin{tabular}{lllll}
\hline |ljciprod01 $\mid$ productn $\backslash \mathrm{C} \backslash \mathrm{CPY} \backslash$ 62-4\CPY402.txt & unknown & Seq: 19 & 29-OCT-15 & 15:26 \\
\hline
\end{tabular}

ings, alleging that those digital performances violated state law. ${ }^{73}$ The desire by owners of pre-1972 recordings to seek compensation for digital public performances on streaming services is understandable: digital streaming revenues for sound recording owners has grown geometrically over the past decade, while income from sales of recordings, including digital downloads, has decreased over time. ${ }^{74}$ Although owners of pre-1972 recordings thus continue to earn revenue from any sales - in the form of physical albums or CDs or in the form of digital downloads on services like iTunes and Amazon - of their works, in the absence of federal or state law recognition of public performance rights in those works, they will be unable to profit from uses of their works in the digital streaming marketplace by webcasters, satellite radio, and Internet streaming services.

Two recent federal district court cases, one interpreting California law and one interpreting New York law, have found those state laws to provide owners of pre-1972 sound recordings a performance right in those sound recordings that was violated by Sirius XM Radio when it digitally streamed the recordings on its Internet radio service. ${ }^{75}$

In the California case, the entity owning the pre-1972 sound recordings by the band The Turtles, Flo \& Eddie, Inc. ("Flo \& Eddie"), sought summary judgment on liability for its state law causes of action arising out of Sirius XM's broadcasting and streaming of sound recordings to subscribers, as well as making reproductions of sound recordings in the operation of its business. ${ }^{76}$ Finding questions of fact that precluded summary judgment relating to the alleged reproductions of Flo \& Eddie's sound recordings made by Sirius XM, the court granted the motion on all causes of action, but solely with respect to the performance of the sound recordings at issue by Sirius XM through its digital broadcasting and streaming

73 See, e.g., Flo \& Eddie, Inc. v. Sirius XM Radio, Inc., 112 U.S.P.Q.2d 1307 (C.D. Cal. 2014); Flo \& Eddie, Inc. v. Sirius XM Radio, Inc., No. 13 Civ. 5784, 2014 WL 7172270 (S.D.N.Y. Nov. 14, 2014).

74 Compare SoundExchange, SoundExchange Fact Sheet (including Chart of Payments 2005-2014), available at http://www.soundexchange.com/ wp-content/uploads/2015/02/SX-Fact-Sheet_2.13.151.pdf (last updated Feb. 13, 2015) (showing collected revenues from online streaming of sound recordings increasing from $\$ 20$ million in 2005 to $\$ 773$ million in 2014), with Scope of the Problem, RIAA, available at http://www.riaa.com/physicalpira cy.php?content_selector=piracy-online-scope-of-the-problem (last visited Mar. 18, 2015) (stating that U.S. music sales dropped 53\%, from $\$ 14.6$ billion in 1999 to $\$ 7.0$ billion in 2013).

75 Flo \& Eddie, Inc., 112 U.S.P.Q.2d 1307; Flo \& Eddie, Inc., 2014 WL 7172270.

76 Flo \& Eddie, Inc., 112 U.S.P.Q.2d at 1310. The plaintiff asserted claims based upon California Civil Code $\$$ 980(a)(2) (California's copyright statute), California Business \& Professional Code $\$ \$ 17200$ et seq. (California's unfair competition law), and common law claims of conversion and misappropriation). 
services. ${ }^{77}$ In finding liability on all four causes of action, the court relied on its interpretation of California Civil Code $\S 980(a)(2)$, the state statute governing copyright in pre-1972 sound recordings, as encompassing the grant of an exclusive right to publicly perform those sound recordings. ${ }^{78}$

The pertinent language in $\S 980(\mathrm{a})(2)$ of the California Civil Code provides:

The author of an original work of authorship consisting of a sound recording initially fixed prior to February 15, 1972, has an exclusive ownership therein until February 15, 2047, as against all persons except one who independently makes or duplicates another sound recording that does not directly or indirectly recapture the actual sounds fixed in such prior recording, but consists entirely of an independent fixation of other sounds, even though such sounds imitate or simulate the sounds contained in the prior sound recording. ${ }^{79}$

The court found that because the "exclusive ownership" provision of the California statute listed only one exception - permitting independent fixation of imitations of the sound recording - the legislature must have intended no other limitations of the ownership right in sound recordings. ${ }^{80}$ Although the court found the statutory language to be unambiguous, it also concluded that its interpretation of that language was consistent with the legislative history of the statute. That history showed that the legislature considered the 1976 Copyright Act in drafting its 1982 amendments to $\S 980(a)(2)$, and thus the court found that the legislature was likely aware of 17 U.S.C. $\S 114(\mathrm{a})$ 's exclusion of performance rights from the rights granted to owners of sound recordings under federal law, yet chose to include no such limitation in its revisions to $\S 980(a)(2) .{ }^{81}$

77 Id. at 1318.

78 Id. at 1312-14, 1317.

79 Cal. Civ. Code $\$ 980(a)(2)$.

80 Flo \& Eddie, Inc., 112 U.S.P.Q.2d at 1311.

81 Id. at 1314. The California Flo \& Eddie opinion also noted that two courts had previously discussed a performance right in sound recordings under $\S 980(a)(2)$, citing Capital Records, LLC v. BlueBeat, Inc., 765 F. Supp. 2d 1198 (C.D. Cal. 2010) and Bagdasarian Prods., LLC v. Capitol Records, Inc., No. B217960, 2010 WL 3245795 (Cal. Ct. App. Aug. 18, 2010) and asserting that both opinions supported its interpretation of $\S 980(a)(2)$ as including a performance right in pre-1972 sound recordings. Id. at 1314. However, neither of these 2010 opinions expressly tackled the question of state law protection for digital performances, let alone whether the federal compulsory licensing system for digital radio services conflicted with any such state law protection. Bagdasarian's use of an example that assumed a state law performance right in a recording if "played during a live stage show" was pure dicta, without any analytical component or support, and did not implicate digital performances. Id. at 1315. BlueBeat did not expressly analyze the question of whether California law grants a performance right to owners of sound recordings; the court simply stated that the defendant 


\begin{tabular}{lllll}
\hline |ljciprod01 $\mid$ productn $\backslash \mathrm{C} \backslash \mathrm{CPY} \backslash$ 62-4\CPY402.txt & unknown & Seq: 21 & 29-OCT-15 & 15:26 \\
\hline
\end{tabular}

In the New York Flo \& Eddie case, the plaintiff brought a putative class action against Sirius XM Radio, alleging claims arising under New York common law copyright and unfair competition laws. ${ }^{82}$ Sirius XM moved for summary judgment, arguing, inter alia, that New York common law copyright protection for pre-1972 recordings afforded no exclusive right of public performance. ${ }^{83}$ The court denied the motion, finding that New York common law protecting pre-1972 sound recordings was broad enough to include a public performance right. The court thus issued an order to show cause why summary judgment on liability should not be entered in favor of the plaintiff. ${ }^{84}$ In so doing, the court recognized that whether New York common law copyright includes a public performance right was a question "of first impression, and one that has profound economic consequences for the recording industry and both the analog and digital broadcast industries." 85 In spite of the court's acknowledgment that its ruling would disrupt the settled expectations of the industry, it reasoned that New York's common law copyright protection for works other than sound recordings encompassed the full "bundle" of rights, including performance rights where applicable. Thus, the court saw no reason to infer that those rights would be more limited for sound recordings in spite of the absence of any judicial recognition of a performance right in sound recordings in the preceding decades and the absence of any efforts by owners of sound recordings to enforce such a common law right. ${ }^{86}$

Litigation in these and some of the related cases is ongoing. The plaintiff in both the California and New York Flo \& Eddie cases has sought class certification on behalf of similarly-situated owners of pre-1972

conceded that it reproduced, sold, and publicly performed the pre-1972 recordings at issue without authorization and concluded that, as a result, it was "liable for misappropriation, unfair competition, and conversion." 765 F. Supp. 2d at 1206. The sole authority cited for that conclusion was $A \& M$ Records, Inc. v. Heilman, 142 Cal. Rptr. 390 (Cal. Ct. App. 1977), but the court mischaracterized the holding in $A \& M$ Records by stating that it held that duplication, sale, and performance of a sound recording without authorization is a classic example of misappropriation, unfair competition, and conversion. Capital Records, 785 F. Supp. 2d at 1206. In fact, $A \& M$ Records involved classic record piracy through unauthorized duplication and sale of records and neither mentioned nor reached any holding about performances of sound recordings. A\& M Records, 142 Cal. Rptr. at 394401.

82 Flo \& Eddie, Inc. v. Sirius XM Radio, Inc., No. 13 Civ. 5784, 2014 WL 7172270 (S.D.N.Y. Nov. 14, 2014).

$83 I d$. at $* 8$.

84 Id. at $* 1, * 10-* 15$.

85 Id. at $* 10$.

86 Id. at $* 10-* 14$. 
recordings. ${ }^{87}$ As of the writing of this article, the federal court in California had denied leave to file an interlocutory appeal of the ruling on liability and was proceeding with the request to certify a class action, but the New York court granted leave to file an interlocutory appeal and proceedings were suspended while the Second Circuit hears the appeal. ${ }^{88}$ Lawsuits alleging similar state law performance rights claims for pre-1972 recordings have also been filed against Pandora Media, Inc. by both Flo \& Eddie and the major labels. ${ }^{89}$

The major record labels had initiated a California state court proceeding against Sirius XM that relied on the reasoning in the California federal Flo \& Eddie case to find a state performance right in sound recordings; although the California Supreme Court denied a petition to review that decision, the case was recently settled for $\$ 210$ million. ${ }^{90}$ In addition, at

87 See, e.g., Flo \& Eddie, Inc. v. Sirius XM Radio, Inc., CV 13-5693, Order Denying Motion to Certify for Interlocutory Appeal (Nov. 20, 2104); Flo \& Eddie, Inc. v. Sirius XM Radio, Inc., CV 13-5693, Order Denying Motion for Reconsideration (Feb. 19, 2015); Flo \& Eddie, Inc. v. Sirius XM Radio, Inc., No. 13 Civ. 5784, Decision and Order (Jan. 15, 2015) (deferring ruling on merits of Flo \& Eddie's motion for summary judgment on liability pending determination of class action certification).

88 See, e.g., Flo \& Eddie, Inc. v. Sirius XM Radio, Inc., No. 13 Civ. 5784, Decision and Order Certifying Interlocutory Appeal (S.D.N.Y. Feb. 10, 2015), leave to appeal granted, No. 15-497 (2d Cir. April 15, 2015); Flo \& Eddie, Inc. v. Sirius XM Radio, Inc., CV 13-5693, Order Denying Motion to Certify for Interlocutory Appeal (C.D. Cal. Nov. 20, 2014) (setting schedule for discovery for class certification and damages). Sirius XM filed a nearly identical motion for summary judgment as to liability in a Florida federal case in 2014, and on June 22, 2015 the United States District Court for the Southern District of Florida granted Sirius XM's motion, concluding that Florida law did not include an express public performance right and that the issue is one "for the Florida legislature." Flo \& Eddie, Inc. v. Sirius XM Radio, Inc., No. 13-23182-CIV, 2015 WL 3852692, at *5 (S.D. Fla. June 22, 2015).

89 See, e.g., Flo \& Eddie, Inc. v. Pandora Media, Inc., No. 2:14-cv-07648 (C.D. Cal. Oct. 14, 2014). In the Pandora litigation in the Central District of California, Pandora filed a motion to dismiss pursuant to California's antiSLAPP statute. The court denied the motion, finding that although Pandora's conduct was protected, speech-related activity under the anti-SLAPP statute, Flo \& Eddie had demonstrated that its state law performance right claims were "sufficiently meritorious" to survive the motion. Flo \& Eddie, Inc. v. Pandora Media, Inc., No. 2:14-cv-07648, Minute Order Denying Pandora's Anti-SLAPP Motion to Dismiss (C.D. Cal. Feb. 23, 2015). That ruling has since been appealed to the Ninth Circuit. Flo \& Eddie, Inc. v. Pandora Media, Inc., No. 15-55287 (9th Cir. Feb. 24, 2015).

90 Capitol Records, LLC v. Sirius XM Radio, Inc., No. BC920581, Court's Ruling (L.A. Sup. Ct. Dec. 5, 2014) (granting reconsideration of Oct. 14, 2014, Order Granting Capitol Record's Motion for a Jury Instruction but reaffirming ruling that California law protected performance rights in sound recordings; also granting certification of interlocutory appeal), petition for review de- 


\begin{tabular}{lllll}
\hline |ljciprod01 $\mid$ productn $\backslash \mathrm{C} \backslash \mathrm{CPY} \backslash$ 62-4\CPY402.txt & unknown & Seq: 23 & 29-OCT-15 & 15:26 \\
\hline
\end{tabular}

least one state legislature is considering enacting a law that would provide owners of pre-1972 sound recordings with an exclusive performance right similar to that recognized by the Central District of California in the Flo \& Eddie litigation. ${ }^{91}$ Thus, in spite of the recent settlement between Sirius $\mathrm{XM}$ and the major labels, the issue of whether state laws provide owners of pre-1972 recordings with remedies against Internet and satellite streaming services is still hotly in dispute.

The rulings in the California and New York cases have been widely acknowledged as potentially devastating to Internet and satellite radio services. ${ }^{92}$ They also serve to provide greater bargaining power to owners of

nied, No. S224881 (Cal. Apr. 29, 2015). In the state court proceedings, the Los Angeles Superior Court initially granted Capitol Records' motion for a jury instruction regarding state law protection of performance rights in sound recordings, relying on the Central District of California opinion in the Flo \& Eddie case to find that such protection existed under California law - but agreed with Sirius XM that any finding of liability would be premature. Capitol Records, LLC v. Sirius XM Radio, Inc., No. BC920581, Court's Ruling on Submitted Matter: Plaintiffs' Motion for Jury Instruction (L.A. Super. Ct., Oct. 14, 2014). After the Superior Court granted Sirius XM's motion for certification for interlocutory appeal in December 2014, the California Court of Appeal summarily denied the writ of mandate, Sirius XM Radio, Inc. v. S.C.L.A., No. B260717 (Cal. Ct. App. 2d App. Dist. Feb. 23, 2015), and Sirius XM filed a petition for review with the California Supreme Court that was denied in April of 2015. Sirius XM Radio, Inc. v. S.C. (Capitol Records), No. S224881 (Cal. Apr. 29, 2015). In late June 2015, the parties announced a settlement of the California state litigation between the major labels and Sirius XM, in which Sirius XM has agreed to pay $\$ 210$ million to the labels, and the labels have consented to continued streaming of their pre-1972 recordings through 2017, with renewal rights subject to mediation. See Ben Sisario, SiriusXM Settles a Lawsuit on Songs Made Before '72, N.Y. TimEs, June 27, 2015, at B3, available at http://www.nytimes .com/2015/06/27/business/sirius-xm-settles-royalty-dispute-over-old-recordings.html?_r=0.

91 See SB 1287, 28th Leg. (Haw. 2015), available at http://www.capitol.hawaii.gov/ session2015/bills/SB1287_SD2_.htm (proposing to make it a misdemeanor to violate the exclusive rights of a pre-1972 sound recording owner).

92 See, e.g., Carlisle, supra note 71; Lee Gesmer, The Kerfuffle Over Copyrights in Pre-1972 Sound Recordings, Mass Law Blog (Oct. 22, 2014), http://masslawblog.com/copyright/the-kerfuffle-over-copyrights-in-pre-1972-sound-recordings; Lee Gesmer, Flo \& Eddie v. Sirius XM - The Other Shoe Drops on the East Coast, Mass LAw BloG (Nov. 19, 2014), http://masslawblog.com/copyright/flo-eddie-v-sirius-xm-the-other-shoe-drops-on-the-east-coast (describing the second ruling against Sirius as potentially "catastrophic," noting that the decisions "create more questions than answers" because of ambiguity about damages under state law, and suggesting that the decision should add pressure on Congress to amend the Copyright Act to protect pre-1972 recordings); Steve Gordon, A California Federal District Court's Decision in a Case Against Sirius XM Has Broader Implications than Just 
\begin{tabular}{lllll}
\hline |ljciprod01 $\mid$ productn $\backslash \mathrm{C} \backslash \mathrm{CPY} \backslash$ 62-4\CPY402.txt & unknown & Seq: 24 & 29-OCT-15 & 15:26 \\
\hline
\end{tabular}

pre-1972 sound recordings than that provided under federal law to owners of sound recordings fixed after February 15, 1972, who are compelled to license their sound recordings to Internet and satellite radio services at rates that some argue are lower than they should be. Because the parties to the Flo \& Eddie cases did not raise, and the courts did not consider, conflict preemption under the Supremacy Clause, the California and New York federal court opinions did not undertake any analysis of whether or how the recognition and enforcement of state law performance rights in digital streaming of sound recordings might interfere with the federal compulsory licensing system established by the Digital Performance Right in Sound Recordings Act of 1995.

\section{PENNIES FROM HEAVEN:93 THE LEGISLATIVE HISTORY OF THE DPRA AND THE COMPLEX STATUTORY \\ PROVISIONS GOVERNING DIGITAL PUBLIC PERFORMANCE RIGHTS IN SOUND RECORDINGS UNDER THE DPRA}

The state law performance rights recognized in the Flo \& Eddie cases come into direct conflict with the goals and purposes of the compulsory statutory licensing provisions of Section 114 of the Copyright Act that were first enacted by Congress in $1995 .{ }^{94}$ By the mid-1990s, the digital era had arrived and it had become possible to make perfect copies of recorded works released in digital format, both by copying them onto compact discs and by transmitting them over the Internet or other digital transmission mechanisms. Although sound recordings that were broadcast over terrestrial radio could be recorded in analog format and sold as a substitute for authorized records, the sound quality of analog recordings was comparatively poor and degraded over time. Record labels became concerned, however, that digital performances of sound recordings through emerging services like satellite radio could be captured in perfect copies and replayed by consumers, serving as a substitute for sales of recordings.

Thus, in response to pleas from record labels for greater protection against digital piracy of sound recordings and after repeated meetings and negotiations with copyright owners, fledgling satellite radio companies, In-

Whether Internet Radio and Satellite Services Must Pay for Pre-1972 Sound Recordings, The Entertainment, Arts and Sports Law Blog (N.Y. State Bar Assoc., Oct. 8, 2014), http://nysbar.com/blogs/EASL/2014/10/a_cal ifornia_federal_district.html.

93 Composed by Arthur Johnston and Johnny Burke, recorded by Frank Sinatra in 1956 and again in 1962.

9417 U.S.C. $\$ 114$ (2012). 


\begin{tabular}{lllll}
\hline |ljciprod01 $\mid$ productn $\backslash \mathrm{C} \backslash \mathrm{CPY} \backslash$ 62-4\CPY402.txt & unknown & Seq: 25 & 29-OCT-15 & 15:26 \\
\hline
\end{tabular}

ternet services, and other interested parties, ${ }^{95}$ Congress passed the 1995 DPRA. ${ }^{96}$ The 1995 DPRA added a limited, digital performance right for sound recordings to section 106 of the Copyright Act, which applied solely to public performances by means of a "digital audio transmission." 97 Additionally, the 1995 DPRA amended the Copyright Act to both define the scope of the new digital public performance right and to create a system for compensating recording artists and copyright owners for uses implicating this right. ${ }^{98}$

The new digital public performance right, as amended by the Digital Millennium Copyright Act, created three different categories of digital audio transmissions, each with separate limitations: exempt transmissions that are permitted without a license or compensation; "a mandatory scheme of "voluntary licensing' for interactive transmissions"; and "a compulsory license scheme for subscription [and eligible nonsubscription] transmissions." 99 The $\S 114$ digital audio transmission categories are summarized below in Figure 1.

The exempt transmissions, even though they are public performances of sound recordings by means of digital audio transmissions, are immune from liability to copyright owners of sound recordings. ${ }^{100}$ The provisions governing exempt transmissions were largely intended to capture traditional terrestrial radio broadcasts even if the broadcast is transmitted digitally, so long as they were broadcast to the public for free rather than limited to subscribers. ${ }^{101}$

95 See S. ReP. No. 104-128, at 13 (1995) (discussing the rationale for providing a digital public performance right and the competing interests at stake).

96 Pub. L. No. 104-39, 109 Stat. 336.

97 Id. As part of the legislative tradeoff that enabled passage of the DPRA, the statute expressly recognized that the new digital performance right in sound recordings would not extend to performances over terrestrial radio. 17 U.S.C. $\$ \S 114(d)(1),(j)(3)(2012)$.

9817 U.S.C. $\$ 114(\mathrm{~d})(2)(2012)$.

992 NimMER \& NimMER, supra note 14, § 8.22[A][1] (recognizing in a footnote the oxymoronic nature of the characterization of the second category as a mandatory scheme of "voluntary" licensing).

10017 U.S.C. $\S 114(d)(1)$ (2012).

101 Both the Copyright Office and the courts have since made it clear that the "exemption" for terrestrial radio does not apply to digital streaming of terrestrial radio broadcasts over the Internet. See, e.g., Public Performance of Sound Recordings: Definition of Service, 65 Fed. Reg. 77,292 (Dec. 11, 2000); Bonneville Int'l Corp. v. Peters, 347 F.3d 485 (3d Cir. 2003). The practical effect of this exemption and subsequent judicial limitation is that when traditional radio stations simultaneously broadcast a program over the air and over a digital Internet stream, those stations are only required to pay royalties to sound recording owners and artists for the digital transmission of the recordings. Other exempt transmissions include retransmissions of nonsubscription broadcasts (even if through a subscription service), 17 
Figure 1: Categories of Digital Audio Transmissions Covered by $\S 114$

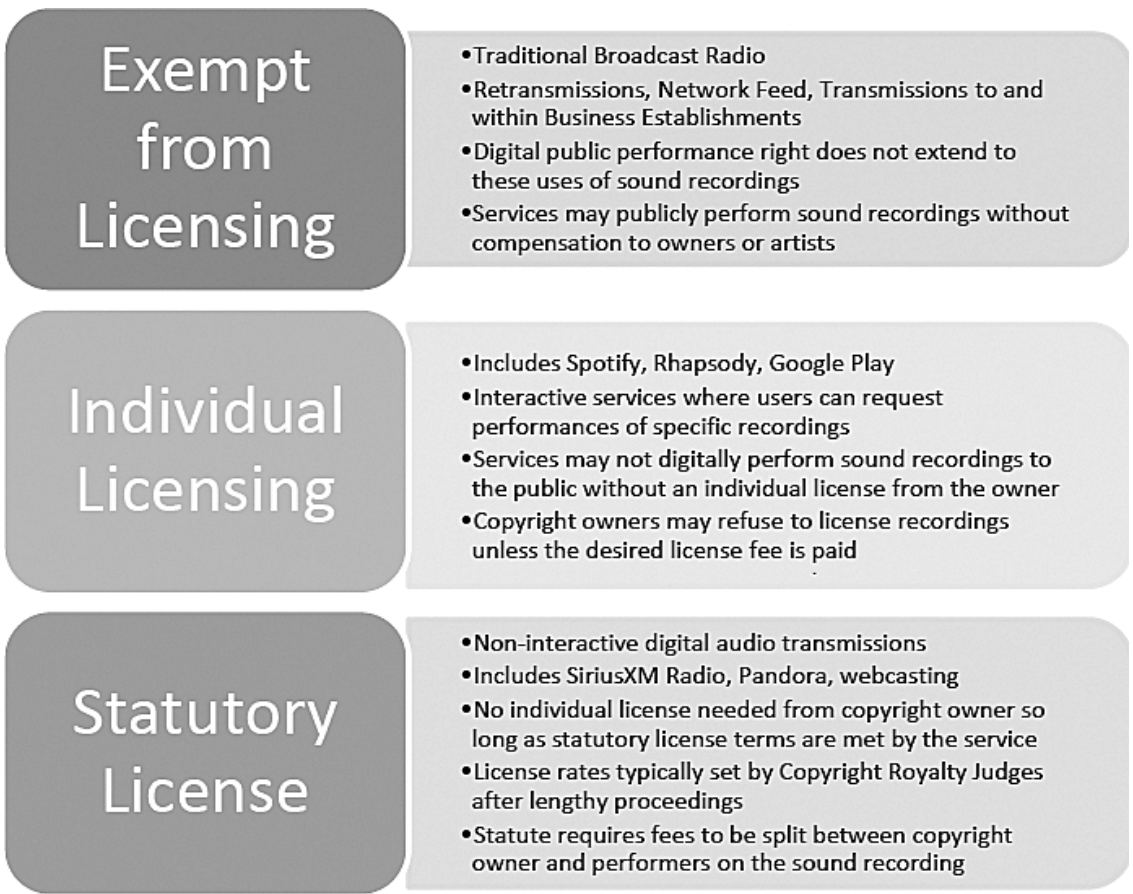

At the other end of the spectrum are interactive services, which must negotiate directly with copyright owners and obtain a license before publicly performing a sound recording via a digital audio transmission. ${ }^{102}$ An

U.S.C. § 114(d)(1)(B) (2012); prior or simultaneous transmissions incidental to an exempt transmission (such as network feed), $i d$. § 114(d)(1)(C)(i); transmissions within a business establishment (i.e., "storecasts"), $i d$. $\S 114(\mathrm{~d})(1)(\mathrm{C})(\mathrm{ii})$; "through to the listener" transmissions where the transmitting entity has a public performance license and has authorized retransmission of the transmissions to its customers (such as in the context of cable systems), id. §114(d)(1)(C)(iii); and transmissions to a business establishment for use in the ordinary course of its business (such as for background music in restaurants or stores), $i d$. § 114(d)(1)(C)(iv). Although a detailed discussion of exempt transmissions is outside the scope of this article, Congress has demonstrated a clear intent in the context of exempt transmissions that no liability attach to the specified activities. Because any efforts to enforce state law performance rights would interfere with that intent, the preemption arguments detailed below in the context of transmissions qualifying for the compulsory statutory license would likely apply equally - or even more strongly - in the context of exempt transmissions under $\S 114$.

10217 U.S.C. § 114(d)(3) (2012). 


\begin{tabular}{lllll}
\hline |ljciprod01 $\mid$ productn $\backslash \mathrm{C} \backslash \mathrm{CPY} \backslash$ 62-4\CPY402.txt & unknown & Seq: 27 & 29-OCT-15 & 15:26 \\
\hline
\end{tabular}

interactive service is defined as a service that "enables a member of the public to receive a transmission of a program specifically created for the recipient," including one allowing a member of the public to receive, "on request, a transmission of a particular sound recording. ..."103 Owners of sound recordings were given the greatest control over digital public performances of their works by interactive services because of the concern that these sorts of "on-demand" services would have the strongest substitutional impact on sales; if listeners could dictate the content of the stream to be able to listen to whatever recordings they desired, then there would be no need for them to purchase the recording. ${ }^{104}$

Finally, and most pertinent to the recent New York and California litigation involving Sirius XM, $\S 114$ created a compulsory statutory licensing system for qualifying "non-interactive" digital audio transmissions of sound recordings. ${ }^{105}$ As a general matter, compulsory statutory licenses have been created by Congress with regard to specific uses of specific types of works to allow for a more efficient mechanism in both guaranteeing public access to works and compensating copyright owners. ${ }^{106}$ Such

103 Id. $\S 114(\mathrm{j})(7)$. The full definition of an "interactive service" is: one that enables a member of the public to receive a transmission of a program specially created for the recipient, or on request, a transmission of a particular sound recording, whether or not as part of a program, which is selected by or on behalf of the recipient. The ability of individuals to request that a particular sound recordings be performed for reception by the public at large, or in the case of a subscription service, by all subscribers of the service, does not make a service interactive, if the programming on each channel of the service does not substantially consist of sound recordings that are performed within 1 hour of the request or at a time designated by either the transmitting entity or the individual making such request. If an entity offers both interactive and noninteractive services (either concurrently or at different times), the noninteractive component shall not be treated as part of an interactive service.

104 See Arista Records, LLC v. Launch Media, Inc., 578 F.3d 148, 154-55 (2d Cir. 2009) (noting that Congress intended the digital public performance right to be "narrow" and that the grant of the right was motivated by the legitimate concerns of record companies about the potential for interactive, on-demand webcasting to substantially reduce record sales).

10517 U.S.C. $\$ 114(d)(2)$ (2012).

106 The first compulsory license created by Congress under its constitutional authority to enact legislation to "promote the Progress of Science and useful Arts," U.S. Const. art. I, § 8, was a mechanical license created under the Copyright Act of 1909 that permitted mechanical recording of a composition if certain conditions were met, including payment of a statutory royalty to the owner of the composition. See Harry G. Henn, The Compulsory License Provisions of the U.S. Copyright Law 2 n.13 (Comm. Print 1956) (General Revision of the Copyright Law, Study No. 5, available at http://www.copyright.gov/history/studies/study5.pdf (discussing section 1(e) 


\begin{tabular}{lllll}
\hline |ljciprod01 $\mid$ productn $\backslash \mathrm{C} \backslash \mathrm{CPY} \backslash$ 62-4\CPY402.txt & unknown & Seq: 28 & 29-OCT-15 & 15:26 \\
\hline
\end{tabular}

licenses impose a limitation on both the owner's ability to control access to the category of works and on the owner's ability to set a price for use of those works by others. ${ }^{107}$ As a result, statutory licenses inevitably reflect both a considered balancing by Congress of the rights of copyright owners and the rights of those who wish to use the works. They also typically encompass a carefully crafted system to define who qualifies for the license and how royalties will be determined and paid. ${ }^{108}$ These characteristics of a statutory license are all reflected in the 1995 DPRA, whereby Congress created an addition to the existing bundle of federal property rights in sound recordings for the benefit of copyright owners - and for the benefit of musical performing artists ${ }^{109}$ - but ensured access to these works by licensees in narrowly defined circumstances through a compulsory statutory license.

of the 1909 Act). Today, Title 17 of the U.S. Code establishes several different types of statutory licenses, many of which apply to musical compositions or sound recordings and their uses in various media, which are administered in part by the Licensing Division of the Copyright Office. See, e.g., 17 U.S.C. § 111(2012) (secondary transmissions by cable systems); id. § 112 (ephemeral recordings); id. $\S 114$ (public performance of sound recordings by means of a digital audio transmission); id. $\S 115$ (use of musical composition in making and distributing phonorecords); id. $\S 118$ (use of certain works in connection with noncommercial broadcasting); id. § 119 (secondary transmissions by satellite carriers); $i d$. $\$ 122$ (secondary transmissions by satellite carriers for local retransmissions); $i d$. $\$ 1001$ et seq. (distribution of digital audio recording devices and media).

107 See generally Scott L. Bach, Music Recording, Publishing, and Compulsory Licenses: Toward A Consistent Copyright Law, 14 Hofstra L. Rev. 379 (1986) (criticizing the mechanical license as providing composers with inadequate control over their works and inadequate compensation for uses of their compositions in sound recordings).

108 Unlike the statutory "mechanical" license for use of musical compositions in sound recordings, which specifies the statutory royalty that must be paid and has been amended over the years to (modestly) increase the statutory rate, see 17 U.S.C. $§ 115$ (2012), the Copyright Act and accompanying regulations generally do not set the specific license rate that must be paid under the section 114 compulsory license. Instead, the DPRA set up a process through which rates and terms are set for specific time periods, subject to periodic adjustment at regular intervals, either by agreement of the different classes of users described under the statute or, failing agreement, by the Copyright Royalty Board, a three-judge panel housed within the U.S. Library of Congress. Id. $\S \S 801(\mathrm{a}),(\mathrm{b})(1)$.

109 Many recording agreements vest ownership of the resulting sound recordings in the record label, not in the recording artists who perform on those sound recordings. Section 114 is a fairly unique aspect of federal copyright law in its express grant of compensation to someone other than the registered copyright owner for uses of the copyrighted work. 


\begin{tabular}{lllll}
\hline |ljciprod01 $\mid$ productn $\backslash \mathrm{C} \backslash \mathrm{CPY} \backslash$ 62-4\CPY402.txt & unknown & Seq: 29 & 29-OCT-15 & 15:26 \\
\hline
\end{tabular}

This careful balancing in the drafting of statutory license provisions adopted under the DPRA is reflected both in the detailed provisions of Section 114 of the Copyright Act and in the legislative history of the statute.

\section{A. All Along the Watchtower:110 Statutory Licensing Provisions of $\S 114$}

The statutory license established by $\S 114$ is precisely tailored to accomplish its intended purpose: to authorize qualifying, radio-like digital services that perform a variety of sound recordings selected by the service (rather than by users) to digitally perform those sound recordings without a license from the copyright owners, provided that a statutory royalty is paid to the designated collective. ${ }^{111}$ Section 114 (d) specifically sets forth the limitations on the digital public performance right in sound recordings established by the DPRA in $\S 106(6)$, including the creation of a statutory license for certain types of digital audio services ${ }^{112}$ making non-interactive ${ }^{113}$ public performances of sound recordings that meet specified eligi-

110 Composed by Bob Dylan; recorded by Jimi Hendrix from January through June 1968, starting in London and completing the final master recording in New York.

111 See S. Rep. No. 104-128, at 16, 24 (1995). For a relatively easy to comprehend summary of the nuances of section 114's distinctions between interactive and non-interactive services and rationale for providing different rate-setting standards for different types of services, see COPYRIGHT AND THE MuSiC MARKetPlace, supra note 5, at 46-52.

112 The statutory license identifies several large categories of platforms and service types that are potentially eligible for the license under 114(d)(2), including "eligible nonsubscription transmission" services (i.e., nonsubscription "webcasting"); "new subscription services" (i.e., subscription webcasting and music channels over cable and satellite television that would come into existence after 1995); "preexisting satellite digital audio radio services" or "SDARS" (i.e., today's combined service known as Sirius $\mathrm{XM}$ ); and "preexisting subscription services" (i.e., subscription digital radio services over cable and satellite television that were in existence in 1995, such MusicChoice and Muzak). Each of these different categories of licensees may be subject to different royalty rates and conditions pursuant to the statutory license, and each may be subject to different license terms under the mechanisms set up for setting rates under the statute. See 2015 Rates, SoundExchangE.com (has links to rate schedules), http://www .soundexchange.com/service-provider/rates (last visited March 19, 2015).

11317 U.S.C. $\S 114(\mathrm{~d})(2)(\mathrm{i})$ (2012). The limitation of the compulsory statutory license to a set of carefully defined, non-interactive services that most resembled traditional terrestrial radio reflects Congress' belief that, among all of the transmission services that were available to the public at the time, interactive services were most likely to substitute for sales of CDs and records and therefore posed the greatest risk to the recording industry. See S. REP. No. 104-128, at 16 (1995). 
bility requirements. ${ }^{114}$ It is a narrowly-crafted (though far from concise) provision that reflects the congressional intent to address the potential impact of new digital music services on the recording industry. The provision also reflects Congress' intent to avoid stifling technology, imposing unnecessary burdens on certain existing distribution services, or adversely affecting existing compensation mechanisms for the public performance of musical works. ${ }^{115}$

Sections 114(e) through (j) address at length a variety of considerations and procedures relating to the implementation of this new statutory license, including:

- the authority for direct negotiations of licenses, ${ }^{116}$

- a limited antitrust exemption for collective negotiations of rates and terms under the statutory license; ${ }^{117}$

11417 U.S.C. $\S 114(d)(2)$ (2012). Those eligibility requirements include that the transmission not be part of an "interactive service," $i d$. $\S 114(\mathrm{~d})(2)(\mathrm{A})(\mathrm{i})$; if technically feasible, the transmission must include "metadata" providing information such as the title and artist of the sound recording, id. $\S 114(\mathrm{~d})(2)(\mathrm{A})(\mathrm{iii})$; the transmission must not exceed the "sound recording performance complement" defined in \$114(j)(13), \$114(d)(2)(B)(i) \& (C)(i); the transmitting entity must not pre-announce the titles of the works performed, id. § 114(d)(2)(B)(ii) \& (C)(ii); "archived" programs available on-demand to the listener must be five or more hours in length and available for no more than two weeks, id. $\S 114(\mathrm{~d})(2)(\mathrm{C})(\mathrm{iii})$; "continuous programs" must be three or more hours in length, $i d$; the transmitting entity must not perform sound recordings as part of an audio-visual work that is likely to cause confusion as to the association of the copyright owner, id. $\S 114(\mathrm{~d})(2)(\mathrm{C})(\mathrm{iv})$; the transmitting entity must take reasonable measures to prevent "scanning" and "stream-ripping" by users, id. § 114(d)(2)(C)(v) $\&$ (vi); the sound recordings used must be "commercially released" by the copyright owner, id. $\S 114(\mathrm{~d})(2)(\mathrm{C})$ (vii); the transmitting entity must not interfere with measures by the owners to identify and protect the copyrighted work, id. $\S 114(\mathrm{~d})(2)(\mathrm{C})$ (viii); and the transmitting entity must textually display to the listener the song title, album title (if any), and the featured artist on the recording, $i d$. $\$ 114(\mathrm{~d})(2)(\mathrm{C})(\mathrm{ix})$.

115 S. ReP. No. 104-128, at 15-16 (1995); H.R. Rep. No. 104-274, at 14 (1995).

11617 U.S.C. $\S 114(\mathrm{e})$ (2012). Although this provision allows direct negotiation between copyright owners and non-interactive streaming services, it does not require licensees to engage in direct negotiations if they prefer to take advantage of the statutory license. This means that a licensee (i.e., a digital streaming service) is able to operate its business without engaging in direct licensing as long as it qualifies for and complies with the requirements of the statutory license, providing for a more efficient licensing system that poses less potential for interference with the growth of the medium. See S. ReP. No. 104-128, at 15-16 (1995); H.R. ReP. No. 104-274, at 14 (1995).

11717 U.S.C. $\S 114$ (e) (2012). The antitrust exemption is a clear indication of how much importance Congress placed on enabling an efficient and successful statutory licensing system. Joint discussions through collective agents are 


\begin{tabular}{lllll}
\hline |ljciprod01 $\mid$ productn $\backslash \mathrm{C} \backslash \mathrm{CPY} \backslash$ 62-4\CPY402.txt & unknown & Seq: 31 & 29-OCT-15 & 15:26 \\
\hline
\end{tabular}

- detailed procedures for setting rates and terms for digital audio services eligible for statutory licensing; ${ }^{118}$

- specific instructions for how licensing proceeds are to be divided among both copyright owners and performers on sound recordings, ${ }^{119}$

- placing limitations on licensing to affiliated entities; ${ }^{120}$ and

- ensuring that compensation for digital public performances of sound recordings would not adversely affect compensation for public performances of musical compositions. ${ }^{121}$

Overlaying the requirements for qualifying for the statutory license are a host of specific procedures and the creation of an administrative apparatus established in $\S 114$ (f) for determining rates for different types of licensees under the statutory license. The statute lays out standards to be applied when setting statutory rates and a rate-setting process that is governed by Copyright Royalty Judges ("CRJs"), an administrative decisionmaking tribunal under the purview of the Library of Congress. ${ }^{122}$ Entities wishing to participate in rate-setting proceedings must file a petition to do so, but once the CRJs have set rates and terms, these rates and terms become binding on all copyright owners and services in the particular class of licensees that use the statutory license and typically cover a five-year period for each class of service. ${ }^{123}$

Although different standards are identified for different types of licensees, some of the factors that the CRJs are required to consider in setting digital streaming royalties for preexisting services (such as Sirius $\mathrm{XM}$ ) under the statutory license are maximizing the availability of works to the public, affording a fair return to copyright owners and a fair income to copyright users, and minimizing any disruptive impact on the relevant industries. ${ }^{124}$ For new subscription services and eligible nonsubscription services (such as Pandora), the CRJs are required to establish "rates and terms that most clearly represent the rates and terms that would have been negotiated in the marketplace between a willing buyer and a willing seller," considering "whether use of the service may substitute for or may promote the sales of phonorecords" and "the relative roles of the copy-

often the only practical way to negotiate rates that will apply across similar categories of licensees and to implement effective statutory licenses.

118 Id. § 114(f).

119 Id. $\S 114(\mathrm{~g})$.

120 Id. $\S 114(\mathrm{~h})$.

121 Id. $\$ 114(\mathrm{i})$.

122 Copyright Royalty and Distribution Reform Act of 2004, Pub. L. No. 108-419, 118 Stat. 2341.

123 See, e.g., 17 U.S.C. § 114(f)(1)(A), (B), § 114(f)(2)(A) \& (B) (2012).

124 See, e.g., id. § 801(b)(1). 
\begin{tabular}{lllll}
\hline |ljciprod01 $\mid$ productn $\backslash \mathrm{C} \backslash \mathrm{CPY} \backslash$ 62-4\CPY402.txt & unknown & Seq: 32 & 29-OCT-15 & 15:26 \\
\hline
\end{tabular}

right owner and the transmitting entity in the copyrighted work and the service made available to the public with respect to relative creative contribution, technological contribution, capital investment, cost, and risk." 125 In addition, the CRJs have authority to establish notice requirements for exercising the statutory license and requirements for maintaining and delivering records - playlists or use logs - that reflect actual use of sound recordings by services taking advantage of the license. ${ }^{126}$

\section{B. The Sound of Silence: ${ }^{127}$ Legislative History of $\$ 114$}

Nowhere in the $\S 114$ statutory license provisions, or even in the grant of a limited digital public performance right in sound recordings in $\S 106(6)$, is there a reference to pre-1972 recordings. There is no evidence whatsoever in the legislative history of the 1995 DPRA that Congress intended to leave the states free to enact or recognize protections for digital performance rights in sound recordings that would interfere with the compulsory statutory license created for the first time in the 1995 DPRA. Instead, a close reading of the legislative history of the 1995 DPRA leads to a conclusion that the omission of express discussion of pre-1972 recordings was the result of Congress' belief (and that of the entire music industry) that no state law performance right in sound recordings existed.

The long history of arguments, studies, and reports about the performance right in sound recordings that preceded the 1995 DPRA reflects an assumption by Congress, the Copyright Office, and all interested parties from the music industry that the 1995 DPRA created a new, narrowlydefined performance right that had not existed for sound recordings under either federal or state law. ${ }^{128}$ The provisions of $\S 114$ and supporting analysis in the Senate and House reports were focused on establishing a streamlined compulsory license system that would both benefit performers and simplify the licensing process for digital streaming services; Congress simply did not consider the possibility that pre-1972 recordings might receive state law protection that would require individual licensing independent of the federal statutory license.

125 Id. $\S 114(\mathrm{f})(2)(\mathrm{B})$. A detailed discussion of the rate-setting process and standards that apply for different types of licensees is outside the scope of this article. For an illustration of how detailed and complex these rate-setting proceedings can be, see In re Digital Performance Right in Sound Recordings and Ephemeral Recordings, Copyright Royalty Board, No. 2009-1 CRB, Webcasting III, Final Determination of Rates and Terms (Jan. 5, 2011, effective Mar. 9, 2011). See generally Andrew Stockment, Internet Radio: The Case for a Technology Neutral Royalty Standard, 95 VA. L. REV. 2129 (2009); Copyright in the Music Marketplace, supra note 5, at 143-44. 12617 U.S.C. § 114(f)(4) (2012).

127 Composed by Paul Simon; recorded by Simon \& Garfunkel in 1964.

128 See supra Sections I(A) and (B). 


\begin{tabular}{lllll}
\hline |ljciprod01 $\mid$ productn $\backslash \mathrm{C} \backslash \mathrm{CPY} \backslash$ 62-4\CPY402.txt & unknown & Seq: 33 & 29-OCT-15 & 15:26 \\
\hline
\end{tabular}

After the bills that led to the 1995 DPRA were first introduced in 1993, the parties affected by the legislation were encouraged to, and did, hold many negotiations and roundtable discussions between representatives of songwriters, performers, unions, performing rights societies, music publishers, broadcast radio, and record companies. ${ }^{129}$ Both the Senate Report and House Report repeatedly noted the careful balance that the 1995 DPRA was striking between multiple competing interests. ${ }^{130}$ It sought to create a narrowly-defined revenue stream for owners of (and performers in) sound recordings whose livelihood was threatened by the advent of online access to and uncompensated downloads of musical recordings. ${ }^{131}$ Congress also sought to protect entities that were engaged in developing what has become one of the preferred sources of music listening for today's consumers - streaming services offering music to consumers in a manner similar to that of terrestrial radio. The statutory license was thus a necessary corollary to the new digital public performance right; it was necessary to streamline the licensing process for digital performances that were "radio-like" and thus were less likely to substitute for sales of recordings. The Senate Report stated,

[T] he Committee has sought to address the concerns of record producers and performers regarding the effects that new digital technology and distribution systems might have on their core business without upsetting the longstanding business and contractual relationships among record producers and performers, music composers and publishers and broadcasters that have served all of these industries well for decades. Accordingly, the Committee has chosen to create a carefully crafted and narrow performance right, applicable only to certain digital transmissions of sound recordings. ${ }^{132}$

129 See, e.g., Digital Performance Right in Sound Recordings Act of 1995 (H.R. 1506): Hearing Before the Comm. on the Judiciary, Subcomm. on Courts \& Intellectual Property, 104th Cong. (June 28, 1995) (statement of Marybeth Peters, Register of Copyrights), available at http://www.copyright.gov/docs/ regstat062895.html (last visited July 24, 2015).

130 S. ReP. No. 104-128, at 15-16 (1995); H.R. ReP. No. 104-274, at 14 (1995).

131 Note that at the time that the 1995 DPRA was negotiated and ultimately enacted, third party online distribution sites for licensed downloads of sound recordings were still almost a decade away from being successfully launched. See, e.g., Pui-Wing Tam \& Anna Wilde Matthews, Apple Polishes Its Music Service, Wall ST. J., Apr. 14, 2003, at B1 (discussing announcement of Apple's planned online distribution site and noting that preexisting record industry sites like PressPlay and MusicNet had been criticized as "too cumbersome" and too limited in both breadth of songs offered and permitted uses of purchased songs).

132 S. REP. No. 104-128, at 13 (1995), quoted in and emphasis added by Bonneville Int'l Corp. v. Peters, 347 F.3d 485, 497 (3d Cir. 2003); see also H.R. REP. 105-796 (Conf. Rep.) at 79-80 (stating that amendments to $\$ \$ 112$ and 114 of the Copyright Act in the Digital Millennium Copyright Act were "in- 


\begin{tabular}{lllll}
\hline |ljciprod01 $\mid$ productn $\backslash \mathrm{C} \backslash \mathrm{CPY} \backslash$ 62-4\CPY402.txt & unknown & Seq: 34 & 29-OCT-15 & 15:26 \\
\hline
\end{tabular}

The intent of Congress to reconcile competing interests in light of changed circumstances in the music industry is a repeated theme in the legislative history:

The limited right created by this legislation reflects changed circumstances: the commercial exploitation of new technologies in ways that may change the way prerecorded music is distributed to the consuming public. It is the Committee's intent to provide copyright holders of sound recordings with the ability to control the distribution of their product by digital transmissions, without hampering the arrival of new technologies, and without imposing new and unreasonable burdens on radio and television broadcasters, which often promote, and appear to pose no threat to, the distribution of sound recordings. ${ }^{133}$

The Senate Report discussed "the need to strike a balance among all of the interests affected" by the new performance right, with that balance "reflected in various limitations on the new performance right" set forth in the 1995 DPRA. ${ }^{134}$ It further expressed the need for the legislation to address concerns about the performance right making it "economically infeasible for some transmitters to continue certain current uses of sound recordings." 135 This balancing process presumed that federal law was the only relevant legal consideration; there is no evidence that Congress factored in the possibility of additional costs on transmitters that might be imposed by owners of pre-1972 sound recordings under state law. Instead, the effects of creating a federal public performance right were measured from a blank slate - i.e., from a starting point in which no compensation was required of those who publicly performed sound recordings, because no public performance right in sound recordings had previously been given legal protection in either state or federal law and the broadcast and music industries had developed based upon that foundation.

Both the House and the Senate Report reflect the belief of Congress that a performance right in sound recordings was necessary to protect recording artists and record companies, but that the right needed to be limited to allow the public to benefit from new digital transmission technologies and to "strike a balance among all of the interests" affected by the new right. ${ }^{136}$ Because of the anticipated continued advancement of

tended to achieve two purposes: first, to further a stated objective of Congress when it passed the [DPRA] to ensure that recording artists and record companies will be protected as new technologies affect the ways in which their creative works are used; and second, to create fair and efficient licensing mechanisms that address the complex issues facing copyright owners and copyright users as a result of the rapid growth of digital audio services").

133 S. REP. No. 104-108, at 15 (1995).

134 S. ReP. No. 104-128, at 15-16 (1995).

135 Id. at 16.

136 Id. at 14; see also H.R. REP. No. 104-274, at 13 (1995). 


\begin{tabular}{lllll}
\hline |ljciprod01 $\mid$ productn $\backslash \mathrm{C} \backslash \mathrm{CPY} \backslash$ 62-4\CPY402.txt & unknown & Seq: 35 & 29-OCT-15 & 15:26 \\
\hline
\end{tabular}

digital transmission technology, both reports stated the intent that "both the rights and exemptions and limitations created by the bill be interpreted in order to achieve their intended purposes."137

Throughout the legislative history of the 1971 SRA, the 1976 Copyright Act revision, and the 1995 DPRA, the baseline presumption was that except for those uses that fell within the digital performance right under federal law, other performances of sound recordings remained in the public domain and were freely permitted without any payment obligation to the owner. ${ }^{138}$ Reports of the Copyright Office associated with those legislative enactments demonstrate a similar understanding that, for example, broadcast radio stations could freely perform sound recordings as part of their business operations without any payment obligation. ${ }^{139}$ Based on the compulsory statutory licensing system established by Congress in 1995 , satellite and digital radio services grew and flourished, with business models relying on the absence of the need for individual licensing negotiations with sound recording owners. As will be discussed in the next section, recent cases recognizing state law performance rights in sound recordings have upset the carefully calibrated federal licensing system and interfere with one of its primary purposes: to simplify and streamline the licensing process for nation-wide streaming services.

137 S. Rep. No. 104-128, at 14 (1995); H.R. Rep. No. 104-274, at 13 (1995).

138 See supra Sections I(A) and I(B). Copyright law exists not just to give legal protection to copyright owners, but also to benefit the public by providing access to creative works. See, e.g., Fogerty v. Fantasy, Inc., 510 U.S. 517, 524 (1994) ("[T]the policies served by the Copyright Act are more complex, more measured, than simply maximizing the number of meritorious suits for copyright infringement," and the monopoly privileges of copyright "are limited in nature and must ultimately serve the public good"); see also Julie L. Ross, A Generation of Racketeers? Eliminating Civil RICO Liability for Copyright Infringement, 13 VAND. J. ENT. \& TECH. L. 55, 111-17 (2010) ("This delicate balance between encouraging artistic creativity through a limited monopoly and promoting wide-spread public access to creative works is unique to copyright and distinguishes it from other contexts. ...”); Julie E. Cohen, Copyright and the Perfect Curve, 53 Vand. L. REv. 1799, 1801 (2000) (describing the two "distinct but related" ways in which copyright law promotes progress in the arts: "it seeks to increase both the quantity and quality of creative output" and "it seeks to broaden public access to creative works").

139 See, e.g., Register of Copyrights, Report on COPYRight IMPlicAtions of Digital Audio Transmission Services 142-57 (Oct. 1991) (summarizing the arguments of interested parties and the Copyright Office's views on granting performance rights to owners of sound recordings, with repeated references to broadcast radio and other entities that perform sound recordings as doing so for "free"). 


\section{SURRENDER:140 THE GOLDSTEIN CASE AND \\ SUPREMACY CLAUSE PREEMPTION CONSIDERATIONS \\ IN THE CURRENT DEBATE OVER STATE LAW \\ PERFORMANCE RIGHTS IN PRE-1972 \\ SOUND RECORDINGS}

Preemption analysis of state laws that overlap with federal copyright law and policy is first analyzed under the express preemption provisions of $\S 301$ of the Copyright Act. ${ }^{141}$ However, the fact that $\S 301$ 's express preemption clause does not apply to pre-1972 sound recordings does not end the inquiry about whether a particular state law that purports to grant copyright-like rights to owners of pre-1972 sound recordings is preempted by federal law. The broad language in the $\S 301$ (c) saving clause - "any rights or remedies under the common law or statutes of any State shall not be annulled or limited by this title until February 15, 2067"142 — might at first glance seem to end the inquiry. However, in addition to any express preemption or saving clause that Congress might incorporate into a statutory framework, the Supremacy Clause of the U.S. Constitution ${ }^{143}$ requires that state law give way to federal law under specific circumstances, including when state laws conflict with federal law. ${ }^{144}$

This "conflict preemption" arises under the Supremacy Clause when a "challenged state law 'stands as an obstacle to the accomplishment and execution of the full purposes and objectives of Congress.'"145 Analyzing whether a conflict exists between state and federal law requires considera-

140 Composed by Doc Pomus and Mort Shuman, recorded by Elvis Presley in 1960 and released in 1961, going on to become one of the best-selling singles in history.

14117 U.S.C. $\$ 301$ (2012).

142 Id. $\S 301(\mathrm{c})$.

143 U.S. Const. art. VI, cl. 2.

144 See, e.g., Geier v. Am. Honda Motor Co., Inc., 529 U.S. 861 (2000); Capital Cities Cable, Inc. v. Crisp, 467 U.S. 691, 698-99 ((1984); Arizona v. United States, 132 S. Ct. 2492, 2501 (2012). The other circumstances in which Supremacy Clause preemption applies are those in which Congress has expressed a clear intent to pre-empt state law; those in which, despite the absence of express preemptive language, Congress has demonstrated an intent to displace state law by creating so pervasive a framework of regulation that it leaves no room for state action; or those in which compliance with both federal and state law is impossible. Capital Cities Cable, 467 U.S. at 699. See generally Robert R.M. Verchick \& Nina Mendelson, Preemption and Theories of Federalism, in Preemption Choice: The Theory, Law, and Reality of Federalism's Core Question 13, 21-22 (William W. Buzbee ed., 2009). None of those alternative Supremacy Clause preemption circumstances is argued to apply here.

145 Capital Cities Cable, 467 U.S. at 699 (quoting Hines v. Davidowitz, 312 U.S. 52, 67 (1941)). 


\begin{tabular}{lllll}
\hline |ljciprod01 $\mid$ productn $\backslash \mathrm{C} \backslash \mathrm{CPY} \backslash$ 62-4\CPY402.txt & unknown & Seq: 37 & 29-OCT-15 & 15:26 \\
\hline
\end{tabular}

tion of the purposes underlying both laws and analysis of how the specific state law at issue interacts with the specific federal law at issue. ${ }^{146}$ The Court's analysis in upholding a state law penalizing reproduction of sound recordings in Goldstein v. California ${ }^{147}$ is a helpful predicate for considering conflict preemption of state laws relating to sound recordings. However its reasoning leads to a different result when applied to the current debate over state law performance rights in pre-1972 sound recordings and how they interact with current federal law instituting a compulsory licensing regime for digital Internet and satellite radio services.

\section{A. Happy Together: ${ }^{148}$ Goldstein's Supremacy Clause Analysis}

The U.S. Supreme Court has only once addressed conflict preemption under the Supremacy Clause in the context of a state law governing sound recordings that was argued to conflict with federal copyright law. In Goldstein, the petitioners were charged under a California statute making it a criminal offense to "pirate" — or physically copy — phonorecords produced by others. ${ }^{149}$ They moved to dismiss the complaint on the grounds that the statute was in conflict with Article 1 , Section 8 , Clause 8 of the United States Constitution and the federal statutes enacted thereunder. ${ }^{150}$

In addressing the Petitioners' preemption arguments, the Court first rejected the argument that all power over copyright had been ceded to the federal government by the states:

146 See, e.g., Kewanee Oil Co. v. Bicron Corp., 416 U.S. 470, 480 (1979); Arizona, 132 S. Ct. at 2503-04.

147412 U.S. 546 (1973).

148 Composed by Gary Bonner and Alan Gordon, recorded by The Turtles in 1967.

149 Goldstein v. California, 412 U.S. 546, 550 (1973). In addressing the Petitioners' arguments, the Court noted that Copyright Act had been amended by Congress while the case was pending in the state courts to allow federal copyright protection for sound recordings, but that section 3 of the amendment specifically provided that "such protection is to be available only to sound recordings 'fixed, published, and copyrighted' on and after February 15, 1972, and before January 1, 1975, and that nothing in Title 17, as amended is to 'be applied retroactively or [to] be construed as affecting in any way any rights with respect to sound recordings fixed before' February 15, 1972." Id. at 552. Because all of the recordings at issue in Goldstein were fixed before February 15, 1972, the Court noted that the 1971 amendments had no application in the appeal before it. Id. However, the opinion predates the 1976 Copyright Act's preemption and saving clauses, as well as the 1995 DPRA, and it addressed a criminal statute relating to physical copying of records - a different right in the "bundle" of exclusive rights that, unlike the public performance right, has always applied to all copyrighted works under both federal and state law.

150 Id. at $548-50$. 
\begin{tabular}{lllll}
\hline |ljciprod01 $\mid$ productn $\backslash \mathrm{C} \backslash \mathrm{CPY} \backslash$ 62-4\CPY402.txt & unknown & Seq: 38 & 29-OCT-15 & 15:26 \\
\hline
\end{tabular}

582 Journal, Copyright Society of the U.S.A.

Although the Copyright Clause thus recognizes the potential benefits of a national system, it does not indicate that all writings are of national interest or that state legislation is, in all cases, unnecessary or precluded. . . . Since the subject matter to which the Copyright Clause is addressed may thus be of purely local importance and not worthy of national attention or protection, we cannot discern such an unyielding national interest as to require an inference that state power to grant copyrights has been relinquished to exclusive federal control. ${ }^{151}$

Noting that its conclusion that the states had not surrendered their power to issue copyrights did "not end the inquiry," 152 the Court went on to evaluate whether the California statute was void under the Supremacy Clause. ${ }^{153}$ It acknowledged that "the conflicts which may develop between state and federal action are as varied as the fields to which congressional action may apply," 154 and the Court thus described its task as determining " "whether, under the circumstances of this particular case, [the state] law stands as an obstacle to the accomplishment and execution of the full purposes and objectives of Congress.'"155

Absent evidence of a specific intent on the part of Congress to preempt state action and the particular area, the Court stated that preemption under the Supremacy Clause may still be found if "Congress so occupied the field of copyright protection as to pre-empt all comparable state action." 156 The petitioners in Goldstein relied heavily on the Court's opinions in Sears ${ }^{157}$ and Compco, ${ }^{158}$ which had previously found state laws granting patent-like protection to designs to be preempted because Congress had intended to occupy the field of patent protection. In both Sears and Compco, the Court emphasized that by excluding certain matters from federal patent protection, Congress intended that those matters be freely accessible to the public. ${ }^{159}$ State laws that limited that free public access were thus found to be preempted. Just as the Court had found to be the case in when Congress chose to exclude certain works from federal patent protection, the petitioners argued that when Congress chose to exempt sound recordings from federal copyright protection in the 1909 Copyright Act, it intended such works to be freely available to the public for

151 Id. at 558 .

$152 I d$. at 561.

153 The Supremacy Clause provides that federal law "shall be the supreme Law of the Land; and the Judges in every State shall be bound thereby, any Thing in the Constitution of Laws of any State to the Contrary notwithstanding." U.S. Const. art. VI, cl. 2.

154 Goldstein, 412 U.S. at 561.

155 Id. (quoting Hines v. Davidowitz, 312 U.S. 52, 67 (1941)).

156 Id. at 567.

157 Sears, Roebuck \& Co. v. Stiffel Co., 376 U.S. 225 (1964).

158 Compco Corp. v. Day-Brite Lighting, Inc., 376 U.S. 234 (1964).

159 Sears, 376 U.S. at 230; see Goldstein, 412 U.S. at 569-70. 


\begin{tabular}{lllll}
\hline |ljciprod01 $\mid$ productn $\backslash \mathrm{C} \backslash \mathrm{CPY} \backslash$ 62-4\CPY402.txt & unknown & Seq: 39 & 29-OCT-15 & 15:26 \\
\hline
\end{tabular}

copying and that state statutes protecting such works would interfere with the balance struck by Congress between protection of authors and public access to works of authorship. ${ }^{160}$ However, the Court distinguished Sears and Compco, noting that the patent laws at issue in those cases reflected a careful balancing by Congress of "the need to encourage innovation and originality of invention against the need to ensure competition in the sale of identical or substantially identical products." 161

In contrast, the Court found no analogous conflict between state and federal law with respect to sound recordings, stating, "In regard to this category of 'Writings,' Congress has drawn no balance; rather, it has left the area unattended, and no reason exists why the State should not be free to act." 162 Reaffirming its decisions in Sears and Compco, the Court found that they had no application to the dispute over the legitimacy of California's statute prohibiting the copying of sound recordings "since Congress has indicated neither that it wishes to protect, nor to free from protection, recordings of musical performances fixed prior to February 15, 1972."163

Goldstein, however, should not be considered to be the last word on whether conflict preemption principles apply to other state laws providing protections to sound recordings that differ both in nature and in their interaction with federal copyright law enacted in the years since Goldstein was decided. Preemption under the Supremacy Clause is a question of how a particular state law interacts with federal law. ${ }^{164}$ Distinct - and difficult - issues are presented regarding the intent of Congress in the series of legislative enactments since Goldstein and how those enactments affect the preemption analysis in the context of a new form of copyright digital audio transmissions - that did not exist when Goldstein was decided.

\section{B. Let Me Go the Right Way:165 Applying Supremacy Clause Preemption Analysis to State Laws Governing Digital Public Performances of Sound Recordings}

As Goldstein made clear, consideration of Supremacy Clause preemption requires two separate inquiries, and both are independent of any express preemption clause or saving clause in a federal statute. ${ }^{166}$

160 Goldstein, 412 U.S. at 551.

161 Id. at 569.

162 Id. at 570.

163 Id. at 571.

164 See Arizona v. United States, 132 S. Ct. 2492, 2503-04 (2012).

165 Composed by Berry Gordy, recorded by the Supremes in 1962.

166 Goldstein, 412 U.S. at 571; Geier v. Am. Honda Motor Co., Inc., 529 U.S. 861 (2000); see also Arizona, 132 S. Ct. at 2503-04. See generally Sandra Zeller, Preemption by Stealth, 45 Hous. L. REv. 1659 (2008-09) (discussing Su- 
\begin{tabular}{lllll}
\hline |ljciprod01 $\mid$ productn $\backslash \mathrm{C} \backslash \mathrm{CPY} \backslash$ 62-4\CPY402.txt & unknown & Seq: 40 & 29-OCT-15 & 15:26 \\
\hline
\end{tabular}

584 Journal, Copyright Society of the U.S.A.

First, the court must consider whether the states have any power at all to regulate the particular area of law - i.e., whether such power was dedicated solely to the federal government under the Constitution or whether the states reserved the power to govern in the area. ${ }^{167}$ In the context of intellectual property, that question has been definitively answered: "the Patent and Copyright Clauses, do not by their own force or by negative implication, deprive the States of the power to adopt rules for the promotion of intellectual creation within their own jurisdictions." 168 States remain free to "promote originality and creativity in their own domains"169 so long as they do so in a manner that is "not inconsistent with federal law." 170 Thus, protection of copyright is not solely within the power of the federal government, but state power to govern in the area of copyright is limited.

The second step in any Supremacy Clause analysis, if it is determined that states do have the power to act in the area, is to determine whether there is any conflict between the particular state law and federal law in question. ${ }^{171}$ "Conflict preemption" arises under the Supremacy Clause either when compliance with both state and federal law is physically impossible or when a "challenged state law 'stands as an obstacle to the accomplishment and execution of the full purposes and objectives of Congress." 172 Where federal intellectual property law has struck a careful balance between the need to promote creativity and the efficient operation of the federal system of protection designed by Congress, "state regulation of intellectual property must yield to the extent that it clashes with

preme Court treatment of saving clauses and preemption in the context of federal regulation of the environment, labor and employment law, products liability, and agricultural practices).

167 Goldstein, 412 U.S. at 552-61; Bonito Boats, Inc. v. Thunder Craft Boats, Inc., 489 U.S. 141, 165-66 (1989); Kewanee Oil Co. v. Bicron Corp., 416 U.S. 470, 478-79 (1979).

168 Bonito Boats, 489 U.S. at 165 (citing Goldstein, 412 U.S. at 552-61).

169 Id.

170 Aronson v. Quick Point Pencil Co., 440 U.S. 257, 262 (1979); Bonito Boats, 489 U.S. at 156.

171 Goldstein, 412 U.S. at 561-62; Kewanee Oil Corp., 416 U.S. at 479.

172 Goldstein, 412 U.S. at 561-62 (quoting Hines v. Davidowitz, 312 U.S. 52, 67 (1941)). See generally Mary J. Davis, On Preemption, Congressional Intent, and Conflict of Laws, 66 U. Pitr. L. Rev. 181, 198-201 (2004-05) (explaining that "obstacle" conflict preemption evaluates congressional purposes for the legislation or regulation at issue rather than congressional intent to preempt and generally arguing that the Supreme Court has implicitly adopted an approach to Supremacy Clause preemption that mirrors government interest analysis in choice of law determinations). 


\begin{tabular}{lllll}
\hline |ljciprod01 $\mid$ productn $\backslash \mathrm{C} \backslash \mathrm{CPY} \backslash$ 62-4\CPY402.txt & unknown & Seq: 41 & 29-OCT-15 & 15:26 \\
\hline
\end{tabular}

the balance struck by Congress. ..."173 In Goldstein, the Court found that no such obstacle existed because the California law in question - one criminalizing unauthorized reproduction of records - provided protection that was not in conflict with federal copyright law or policy, as Congress at the time had expressed no interest in either protecting pre-1972 sound recordings or freeing them from protection. ${ }^{174}$ However, the Court's reasoning in Goldstein cannot be mechanically applied to all state laws that arguably apply to pre-1972 sound recordings. The specific state law in question must be evaluated in light of current federal law and policy, examining the objectives of both areas of law to determine whether the state law clashes with federal law and whether a saving clause precludes preemption in spite of the particular conflict that might be found. ${ }^{175}$

173 Bonito Boats, 489 U.S. at 152 (recognizing careful balance in federal patent laws between need to promote innovation and the ability to exploit inventive resources and applying conflict preemption to invalidate Florida statute prohibiting use of a direct molding process to duplicate unpatented boat hulls because the statute conflicted with a strong federal policy favoring free competition in ideas not qualifying for patent protection).

174 Goldstein, 412 U.S. at 569, 571.

175 Arizona v. United States, 132 S. Ct. 2492, 2503-04 (2012); see also Kewanee Oil Co. v. Bicron Corp., 416 U.S. 470, 480 (1979); Geier v. Am. Honda Motor Co., Inc., 529 U.S. 861, 868 (2000). Professor Pulsinelli has also engaged in a conflict preemption analysis regarding state and federal laws governing public performances of sound recordings, in an article published just as this one was submitted for publication. Gary Pulsinelli, Happy Together? The Uneasy Coexistence of Federal and State Protection for Sound Recordings, 82 Tenn. L. Rev. 167 (2014). Professor Pulsinelli agrees that state law recognition of a public performance right in sound recordings presents a conflict preemption problem, focusing primarily on the interests in uniformity underlying federal copyright law and the lack of a local, state interest in nation-wide digital transmissions that might outweigh the federal interest in uniformity. Id. at 208-17. This article views conflict preemption through a narrower lens, focusing on specific conflicts created by applying state law to transmissions covered by the federal compulsory licensing system rather than all forms of digital transmissions. Because Congress was willing to tolerate some lack of uniformity in law regarding sound recordings when it opted to exclude pre-1972 sound recordings from federal protection and to preserve state law protections for those recordings, the general federal interest in uniformity of copyright law by itself may not provide sufficient basis for preempting state laws - at least not without considering the language and purposes of a particular federal statutory provision. The necessity of uniformity in a particular area of law is certainly an important policy consideration in preemption analysis. See, e.g., Verchick \& Mendelson, supra note 144, at 32 (explaining that the "basic values at stake in the preemption debate" are "a concern for local democracy and state experimentation, on one side, and a desire for national uniformity and efficiency on the other"). Professor Pulsinelli persuasively distinguishes Goldstein based on changes in the music industry wrought by technological development over 


\begin{tabular}{lllll}
\hline |ljciprod01 $\mid$ productn $\backslash \mathrm{C} \backslash \mathrm{CPY} \backslash$ 62-4\CPY402.txt & unknown & Seq: 42 & 29-OCT-15 & 15:26 \\
\hline
\end{tabular}

1. I Walk the Line: ${ }^{176}$ Analyzing the Objectives of the State and Federal Laws at Issue

The application of conflict preemption principles in this situation where Congress has stepped in with a comprehensive federal program after courts had previously ruled that state laws were not preempted - is implicated by the Supreme Court's analysis in Arizona v. United States. ${ }^{177}$ There, the Court considered whether four separate provisions of an Arizona statute aimed at addressing the problem of illegal immigration were preempted under the Supremacy Clause. ${ }^{178}$ Noting the "extensive and complex" federal governance of immigration and alien status, ${ }^{179}$ the Court deemed it necessary to review each of the four provisions to determine how the particular provision - not the law as a whole - interacted with federal immigration laws to evaluate whether preemption applied to the specific provision. ${ }^{180}$

Of particular relevance here is the Court's discussion of section 5(C) of the Arizona law, which made it a misdemeanor for unauthorized aliens to "apply for work, solicit work in a public place, or perform work as an employee or independent contractor" in Arizona. ${ }^{181}$ Before there had been any "comprehensive federal program regulating the employment of unauthorized aliens," 182 the Court had upheld a California statute regulating employment of aliens against a preemption challenge, finding that "States possess broad authority under their police powers to regulate the employment relationship to protect workers within the State."183 However, at the time, "the Federal Government had expressed no more than 'a peripheral concern with [the] employment of illegal entrants." "184 In Arizona, the Court found that because federal law had changed and a comprehensive framework relating to employment of illegal aliens had been

the decades since the 1976 Act and the resulting changed balance between federal and state interests in protecting copyright that weakens the "local democracy" and "state experimentation" side of the equation in preemption analysis of sound recording rights. However, this article focuses more specifically on the objectives of the federal compulsory license system for digital audio transmissions reflected in the structure of section 114 and its legislative history than on the overarching interest in national uniformity within the federal Copyright Act.

176 Composed by Johnny Cash and recorded by Johnny Cash in 1956.

177132 S. Ct. 2492 (2012).

178 Id. at 2497.

179 Id. at 2499.

180 Id. at 2501-02.

181 Id. at 2503.

182 Id.

183 Id. (citing De Canas v. Bica, 424 U.S. 351, 356 (1976)).

184 Id. (quoting De Canas, 424 U.S. at 360). 


\begin{tabular}{lllll}
\hline |ljciprod01 $\mid$ productn $\backslash \mathrm{C} \backslash \mathrm{CPY} \backslash$ 62-4\CPY402.txt & unknown & Seq: 43 & 29-OCT-15 & 15:26 \\
\hline
\end{tabular}

put into place, with a deliberate choice by Congress to not impose criminal penalties on aliens who seek to work in the U.S., the Arizona law "would interfere with the careful balance struck by Congress." 185

As Goldstein recognized and as $\S 301$ (c) confirms, the states possess broad authority to protect pre-1972 sound recordings. However, just as the states' interest in regulating employment in Arizona did not outweigh a subsequently-enacted federal regime when specific state laws interfered with its ability to accomplish its objectives, neither should states' continuing interests in and power to protect pre-1972 recordings be permitted to interfere with the goals and objectives of the national compulsory licensing regime enacted by Congress for digital performances of sound recordings. ${ }^{186}$

The Supreme Court had the opportunity to evaluate a conflict between the objectives of state and federal law similar to the one at issue here in Capital Cities Cable, Inc. v. Crisp. ${ }^{187}$ In Capital Cities Cable, Inc., the federal regulation of cable television by the F.C.C. and comprehensive compulsory copyright licensing system for retransmissions of copyrighted broadcasts over cable television were found to preempt an Oklahoma statute that prohibited broadcasts of advertisements for alcoholic beverages. ${ }^{188}$ In analyzing the conflict between the Oklahoma statute and the

185 Id. at 2504-05. The Court also found that the existence of an express preemption provision in the relevant federal statute had no affect on the Supremacy Clause preemption analysis, in spite of the fact that the preemption provision barred states from penalizing employers of unauthorized aliens but was silent about whether states could penalize the employees themselves. $I d$.

186 The fact that states are given broad authority over pre-1972 sound recordings is not inconsistent with this result. In preempting a Virginia law that purported to allow a surviving spouse to receive federal life insurance benefits from an insured who had listed an ex-spouse as the designated beneficiary, the Supreme Court noted that even though "regulation of domestic relations is traditionally in the domain of state law" and thus that there is a " 'presumption against pre-emption' of state laws governing domestic relations," state domestic relations laws must still give way when they present a clear conflict with federal law. Hillman v. Maretta, 133 S. Ct. 1943, 1950 (2013). Similarly, the 1995 DPRA does not supplant all state law protections for pre-1972 sound recordings — only those that are in conflict with the limits it placed on digital public performance rights in order to establish a national statutory license regime.

187467 U.S. 691 (1984).

$188 \mathrm{Id}$. at 716 . In addressing the conflict between F.C.C. regulations requiring that cable systems carry certain broadcast programming without changing it and the state statute's requirement that cable services in Oklahoma remove alcoholic beverage advertisements from that programming, the Court discussed the history of F.C.C. regulation of cable systems, noting that the F.C.C. expressly adopted "a program of 'deliberately structured dualism' in 


\begin{tabular}{lllll}
\hline |ljciprod01 $\mid$ productn $\backslash \mathrm{C} \backslash \mathrm{CPY} \backslash$ 62-4\CPY402.txt & unknown & Seq: 44 & 29-OCT-15 & 15:26 \\
\hline
\end{tabular}

purposes and goals of the provisions of the Copyright Act relating to the statutory license for cable television retransmissions of copyrighted works, the Court stated:

Congress has considered the impact of this new technology, and has, through the Copyright Revision Act of 1976, 90 Stat. 2541, 17 U.S.C. $\S 101$ et seq., acted to facilitate the cable industry's ability to distribute broadcast programming on a national basis.... In revising the Copyright Act, however, Congress concluded that cable operators should be required to pay royalties to owners of copyrighted programs retransmitted by their systems on pain of liability for copyright infringement. At the same time, Congress recognized that "it would be impractical and unduly burdensome to require every cable system to negotiate [appropriate royalty payments] with every copyright owner" in order to secure consent for such retransmissions. Copyright Law Revision, H.R. Rep. No. 94-1476, p. 89 (1976). Section 111 of the 1976 Act codifies the solution devised by Congress. It establishes a program of compulsory copyright licensing that permits cable systems to retransmit distant broadcast signals without securing permission from the copyright owner and, in turn, requires each system to pay royalty fees to a central royalty fund based on a percentage of its gross revenues. ${ }^{189}$

The Court also noted that the compulsory licensing system devised by Congress included specific requirements for cable systems to take advantage of the protections afforded by the statutory license ${ }^{190}$ and Congress' recognition of the "virtually insurmountable and logistical problems" that cable operators would face if they were required to edit or block programs

which state and local authorities were given responsibility for granting franchises to cable operators within their communities and for overseeing such local incidents of cable operations as delineating franchise areas, regulating the construction of cable facilities, and maintaining rights of way." Id. at 702 (quoting Cable Television Report and Order, 36 F.C.C.2d 143, 207 (1972), aff'd sub nom., Am. Civil Liberties Union v. Fed. Commc'ns Comm., 523 F.2d 1344 (9th Cir. 1975)). In a series of rulings, later upheld by the courts, the F.C.C. delineated the scope of federal regulation of cable services, specifically precluding states from regulating rates or signal carriage for cable systems. Id. at 702-03. The federal interests justifying such exclusive federal control over aspects of cable systems were the need to "assure the orderly development of this new technology into the national communications structure," id. at 703 n.8 (quoting Duplicative and Excessive Over-Regulation-CATV, 54 F.C.C.2d 855, 863 (1975)), and providing increased viewing options and a diversity of services to the public. Id. at 704 (citing CATV Syndicated Program Exclusivity Rules, 79 F.C.C.2d 663, 746 (1980). Similar federal interests govern the establishment of a federal licensing system for Internet and satellite radio, both of which are inherently national in scope and, at the time that the 1995 DPRA was enacted, were emerging technologies that Congress did not want to suppress when it granted a limited public performance right.

$189 \mathrm{Id}$. at 709-10 (footnote omitted).

190 Id. at 710 . 


\begin{tabular}{lllll}
\hline |ljciprod01 $\mid$ productn $\backslash \mathrm{C} \backslash \mathrm{CPY} \backslash$ 62-4\CPY402.txt & unknown & Seq: 45 & 29-OCT-15 & 15:26 \\
\hline
\end{tabular}

as to which they were unable to obtain direct copyright permissions from the owners. ${ }^{191}$ The Court stated:

In devising this system, Congress has clearly sought to further the important public purposes framed in the Copyright Clause, U.S. Const., Art. 1, $\S 8$, of rewarding the creators of copyrighted works and of "promoting broad public availability of literature, music, and the other arts." Compulsory licensing not only protects the commercial value of copyrighted works but also enhances the ability of cable systems to retransmit such programs carried on television broadcast signals. By requiring cable operators to delete commercial advertisements for wine, however, the Oklahoma ban forces these operators to lose the protections of compulsory licensing. Of course, it is possible for cable systems to comply with the Oklahoma ban by simply abandoning their importation of the distant broadcast signals covered by the Copyright Act. But such a loss of viewing options would plainly thwart the policy identified by both Congress and the FCC of facilitating and encouraging the importation of distant broadcast signals. ${ }^{192}$

Similar concerns led to the compulsory licensing system for digital radio services: obtaining the rights to broadcast a full range of sound recordings to support an online or satellite radio service would have created an insurmountable obstacle for fledgling digital radio services, particularly in light of the fact that they were competing with terrestrial radio, which the 1995 DPRA expressly exempted from any licensing or royalty obligation. ${ }^{193}$ If states were permitted to require separate licenses for use of pre-1972

191 Id. n.13.

192 Id. at 710-11 (quoting Twentieth Century Music Corp. v. Aiken, 422 U.S. 151, 156 (1975) and citing Sony Corp. v. Universal City Studios, Inc., 464 U.S. 417, 428-29 (1984)).

193 Although Congress did not want to place the burden of negotiating individual licenses on non-interactive digital transmission services that provided radiolike services, interactive services that did not qualify for the statutory license were expected to go through that process. For example, Spotify, a primarily on-demand Swedish streaming service that is gaining in popularity in the United States, delayed its launch into the United States market for almost two years while it negotiated licenses with all of the major labels. See, e.g., Ben Sisario, New Service Offers Service in Quantity, Not by Song, N.Y. Times, July 14, 2011, at B1, available at http://www.nytimes.com/2011/ 07/14/technology/spotify-music-streaming-service-comes-to-us.html?_r=0. In 2014, recording artist Taylor Swift made headlines when she refused to license her new album to Spotify and pulled all but one of her existing songs from the service, contending that Spotify was not offering high enough license fees in the per-stream rate it offered. See Jack Linshi, Here's Why Taylor Swift Pulled Her Music from Spotify, Time (Nov. 3, 2014), http://time .com/3554468/why-taylor-swift-spotify. Interactive streaming services like Spotify that do not qualify for the section 114 statutory license are thus at the mercy of individual recording owners who are free to withhold their music, whereas the compulsory license created by Congress for non-interactive streaming services was designed to make all recordings available to 


\begin{tabular}{lllll}
\hline |ljciprod01 $\mid$ productn $\backslash \mathrm{C} \backslash \mathrm{CPY} \backslash$ 62-4\CPY402.txt & unknown & Seq: 46 & 29-OCT-15 & 15:26 \\
\hline
\end{tabular}

works on Internet and satellite radio services, these services would likely end up limiting the availability of pre-1972 sound recordings on their stations, a result that benefits neither the public nor owners of pre-1972 recordings.

Although Capital Cities Cable, Inc. involved a situation where the F.C.C. had precisely delineated the scope of permitted state regulation of cable services and the Oklahoma statute went beyond those limits, ${ }^{194}$ there the state had perhaps a stronger argument for its authority than that presented by the saving clause in $\S 301$ (c). Oklahoma relied on the Twenty-First Amendment in asserting that the Constitution had relegated regulation of alcoholic beverages to the states, but the Court, weighing the strength of the interests underlying the Twenty-First Amendment and those underlying the compulsory licensing provisions of the Copyright Act, concluded that the federal interest in the uniform application of the compulsory license and F.C.C. regulations governing carriage of cable signals trumped the state's interest in regulating alcohol. ${ }^{195}$ The regulation of television advertisements for alcohol was only a small aspect of the state's ability to regulate alcohol in its territory that had not previously been applied to cable services, and thus the impact of preemption was minimal on the state's overall regulation of alcohol. ${ }^{196}$ Similarly, in the context of the digital public performance right in sound recordings, the states have not previously recognized or protected such a right, and federal preemption of that right would have no impact on the state's ability to protect other uses of pre-1972 sound recordings that implicate different rights in the bundle of protections offered to copyright owners of sound recordings.

\section{Saved: ${ }^{197}$ The $\S 301(c)$ Saving Clause Does Not Preclude Supremacy Clause Preemption}

The presence of an express statutory preemption provision and saving clause for state laws governing pre-1972 sound recordings ${ }^{198}$ presents a separate interpretive hurdle in the preemption analysis, but it does not necessarily preclude the application of ordinary conflict preemption principles. ${ }^{199}$ Yet, Sirius XM did not argue and neither federal court in the Flo

those non-interactive services without the need to negotiate individual licenses.

194 Capital Cities Cable, 467 U.S. at 711.

195 Id. at $715-16$

196 Id.

197 Composed by Jerry Leiber and Mike Stoller; recorded by Lavern Baker in 1961.

19817 U.S.C. $\S 301$ (2012).

199 See, e.g., Geier v. Am. Honda Motor Co., Inc., 529 U.S. 861 (2000). 


\begin{tabular}{lllll}
\hline |ljciprod01 $\mid$ productn $\backslash \mathrm{C} \backslash \mathrm{CPY} \backslash$ 62-4\CPY402.txt & unknown & Seq: 47 & 29-OCT-15 & 15:26 \\
\hline
\end{tabular}

\& Eddie cases addressed whether the Supremacy Clause preempted the state law rights asserted by the plaintiff. ${ }^{200}$ The California district court's sole discussion of preemption was a brief mention of the express preemption provision the Copyright Act in concluding that, pursuant to $\S 301$ (c), "the Federal Copyright Act does not apply to [pre-1972] recordings and explicitly allows states to continue to regulate them."201 However, this conclusion should only have been the start of any consideration of whether the state laws at issue would be preempted by federal copyright law, not the end of it; it does not answer the question of whether the Supremacy Clause precludes enforcement of state law in connection with specific types of digital performances of sound recordings. ${ }^{202}$

The New York court in the Flo \& Eddie litigation went a step further than the California court, more closely analyzing § 301(c) and its interaction with the Commerce Clause. ${ }^{203}$ The Southern District of New York

200 Instead, Sirius relied on the dormant Commerce Clause, asserting that applying state laws protecting public performance rights to its satellite broadcasting activities would control commerce outside any individual state's borders and thus would run afoul of the Commerce Clause. See, e.g., Defendant's Memorandum of Points and Authorities in Opposition to Plaintiff's Motion for Summary Judgment at 20-22, No. CV 13-5693 (C.D. Cal. July 7, 2014); Defendant Sirius XM's Motion for Summary Judgment on Liability and Supporting Memorandum of Law at 18-20, No. 1:13-CV-23182 (S.D. Fla. July 15, 2014). In both briefs, Sirius XM argued that allowing owners of pre-1972 sound recordings to assert state law-based digital performance rights would interfere with the elaborate compulsory licensing system established by the DRPA in 1995, but presented that argument as a policy reason for refusing to find a state law right rather than as a reason for Supremacy Clause preemption.

201 Flo \& Eddie, Inc. v. Sirius XM Radio, Inc., 112 U.S.P.Q.2d 1307, 1311 (C.D. Cal. 2014) (citing 17 U.S.C. $§ 301(c)$ ). In a footnote, the court briefly addressed and rejected Sirius XM's dormant Commerce Clause argument, asserting: "Because Congress specifically authorized protection of pre-1972 sound recording rights by the states in 17 U.S.C. $\$ 301(\mathrm{c})$, the California statute protecting those rights is not subject to the Commerce Clause." Id. at 1315 n.1. Professor Gary Pulsinelli has argued that the dormant Commerce Clause preempts a proposed Tennessee statute giving state law protections to public performances of sound recordings, as well as the state laws at issue in the Flo \& Eddie litigation. Pulsinelli, supra note 175, at 21734. This article takes no position on the dormant Commerce Clause argument, other than to assert that Supremacy Clause preemption is a stronger basis on which to invalidate the state law claims at issue. See, e.g., Viet D. Dinh, Reassessing the Law of Preemption, 88 GEO. L.J. 2085, 2098 \& Fig. 1 (2000) (discussing and illustrating the spectrum of doctrinal mechanisms through which federal law displaces state law).

202 See Goldstein v. California, 412 U.S. 546, 571; Arizona v. United States, 132 S. Ct. 2504-05 (2012).

203 Flo \& Eddie, Inc. v. Sirius XM Radio, Inc., No. 13 Civ. 5784, 2014 WL 7172270, at $* 21$ (S.D.N.Y. Nov. 14, 2014). 
Flo \& Eddie opinion addressed the language of $\S 301(\mathrm{c})$ in the context of whether it demonstrated an intent by Congress to preclude Commerce Clause challenges to assertion of state law rights in pre-1972 recordings. ${ }^{204}$ However, its reasoning applies equally in the context of conflict preemption under the Supremacy Clause. The court stated:

I note that $\S 301$ (c) is contained in the section of the federal copyright law that addresses the law's preemptive scope. Thus, the language cited by Flo and Eddie could plausibly be interpreted, not to allow states to impose otherwise unconstitutional burdens on interstate commerce, but only to limit the scope of federal copyright law - by excluding, for a period of time, otherwise preempted state laws from the preemptive reach of 17 U.S.C. $\S 301(a)$. Under this interpretation, although $\S 301$ (c) broadly reaches "any" state right or remedy, it shields state regulation only from statutory preemption, not from Commerce Clause scrutiny. ${ }^{205}$

Finding it reasonable to interpret $\S 301$ (c) "as a provision about federal statutory preemption, and not as an authorization for states to interfere with interstate commerce," the court rejected Flo \& Eddie's assertion that the use of the term "any" in $\S 301$ (c) demonstrated an intent by Congress to permit "all" state laws regulating pre-1972 recordings. ${ }^{206}$ The Copyright Office has also agreed with the proposition that "section 301(c) does not prohibit all subsequent [federal] regulation of pre-1972 recordings."207

204 Id

205 Id.

206 Id. at *22. The court went on, however, to reject Sirius XM's argument based on the dormant Commerce Clause because it concluded that New York common law on copyright "does not 'regulate' anything," but is simply a recognition of a property right. $I d$. at $* 22-23$.

207 Copyright Protection for Pre-1972 Sound Recordings, supra note 6, at 131 (quoting Capitol Records, Inc. v. MP3Tunes LLC, 821 F. Supp. 2d 627, 641 (S.D.N.Y. 2011), but disagreeing with that opinion's ultimate conclusion that 17 U.S.C. $\$ 512$ "safe harbors" applied to pre-1972 sound recordings). Moreover, the Copyright Office has suggested that even though $\S 301$ (c) was never amended after the Uruguay Round Agreement Act was passed in 1994, bringing foreign pre-1972 sound recordings under federal copyright protection, under the reasoning of Goldstein, an argument could be successfully made that Congress has no longer left the question of protection for restored foreign recordings "unattended," and thus conflicting state laws are preempted. Id. at 19 . In the Ringer Report, supra note 30, at 19-20, the Copyright Office discussed Goldstein at length, describing it as "surprising" in light of the Sears/Compco decisions but reasoning that the Court was distinguishing between situations in which state law "may possibly" lead to conflicts with federal laws and those in which conflicts will necessarily arise. Focusing on sound recordings fixed between 1972 and 1978, as to which it was unclear whether any state law performance rights could be applied, the Copyright Office Report reasoned that state law performance rights in post1978 sound recordings would be clearly preempted, and that any state law performance rights in pre-1972 recordings were expressly preserved, but 


\begin{tabular}{lllll}
\hline |ljciprod01 $\mid$ productn $\backslash \mathrm{C} \backslash \mathrm{CPY} \backslash$ 62-4\CPY402.txt & unknown & Seq: 49 & 29-OCT-15 & 15:26 \\
\hline
\end{tabular}

Similar reasoning applies in the context of conflict preemption under the Supremacy Clause. The language of $\S 301(\mathrm{c})$ is intended to, and clearly does, exempt state laws governing pre-1972 sound recordings from statutory preemption under $\S 301(\mathrm{a})$. What it does not do is preclude any consideration or analysis of whether a specific state law conflicts with the goals and purposes of a specific aspect of federal copyright law under the Supremacy Clause of the United States Constitution. Even though $\S 301$ (c) serves as a "saving clause" with respect to statutory preemption of state laws governing pre-1972 recordings, it is no different from saving clauses in other federal statutes that have failed to limit the application of ordinary conflict preemption principles under the Supremacy Clause. ${ }^{208}$

For example, in Geier v. American Honda Motor Co., Inc. ${ }^{209}$ the Court found that a saving clause in the express preemption provision of the National Traffic and Motor Vehicle Safety Act of $1966^{210}$ did not preclude consideration of ordinary conflict preemption principles. The saving clause at issue in Geier stated that "[c]ompliance with" a federal safety standard "does not exempt any person from any liability under common law," 211 thus mirroring the "any rights or remedies" language of $\S 301(\mathrm{c})$. The Court found that "the savings clause (like the express pre-emption provision) does not bar the ordinary working of conflict pre-emption principles," 212 noting that "this Court has repeatedly 'decline[d] to give broad effect to saving clauses where doing so would upset the careful regulatory scheme established by federal law." 213

Although $\S 301(\mathrm{c})$ must be interpreted to preserve some aspects of state law protecting pre-1972 sound recordings, it cannot be that the language of $\S 301$ (c) serves as a blanket grant of authority in perpetuity — or

that state law performance rights in 1972-78 sound recordings could be preempted under the reasoning of Sears/Compco and Goldstein if the particular state law were found to conflict with federal policy. Id. at 20. This reasoning is not inconsistent with the position taken in this article, as it was premised upon the fact that, in 1978, Congress had elected to provide no federal performance right in sound recordings, $i d$., and thus there was no basis for considering whether state law protection of performance rights in pre-1972 sound recordings would necessarily conflict with federal copyright law. After 1995, with the comprehensive statutory licensing system that was established for digital performance rights in sound recordings, such a conflict became real and requires a revisiting of any conclusions reached before federal law had granted any protection or created a comprehensive compulsory licensing system for digital performance rights.

208 See, e.g., Geier v. Am. Honda Motor Co., Inc., 529 U.S. 861 (2000).

209 Id.

210 Pub. L. No. 89-563, 80 Stat. 718 (currently codified at 15 U.S.C. § 1391-1431).

211 Geier, 529 U.S. at 868 (quoting 15 U.S.C. § 1397(k) (1988 ed.)).

212 Id. at 869.

213 Id. at 870 (quoting United States v. Locke, 529 U.S. 89, 106-07 (2000)). 
\begin{tabular}{lllll}
\hline |ljciprod01 $\mid$ productn $\backslash \mathrm{C} \backslash \mathrm{CPY} \backslash$ 62-4\CPY402.txt & unknown & Seq: 50 & 29-OCT-15 & 15:26 \\
\hline
\end{tabular}

at least until 2067 - for states to pass any laws that they see fit or to interpret their common law to grant new property rights with respect to pre-1972 sound recordings, regardless of how those laws might conflict with any subsequent federal copyright legislation. Like the saving clause in Geier, it expresses no congressional intent to foreclose the application of ordinary conflict preemption principles, but merely limits the scope of the statutory preemption provision. As the Court reasoned in Geier:

Why, in any event, would Congress not have wanted ordinary pre-emption principles to apply where an actual conflict with a federal objective is at stake? Some such principle is needed. In its absence, state law could impose legal duties that would conflict directly with federal regulatory mandates. . . . Insofar as petitioner's argument would permit commonlaw actions that "actually conflict" with federal regulations, it would take from those who would enforce a federal law the very ability to achieve the law's congressionally-mandated objectives that the Constitution, through the operation of ordinary pre-emption principles, seeks to protect. To the extent that such an interpretation of the saving provision reads into a particular federal law toleration of a conflict that those principles would otherwise forbid, it permits that law to defeat its own objectives, or potentially, as the Court has put it before, to "destroy itself." 214

Similarly, § 301(c) simply limits the scope of the statutory preemption of state law protections provided for in $\S 301(a)$; it does not hamper Congress' ability to subsequently limit state law protections, as it may do in the ongoing copyright revision process, ${ }^{215}$ nor does it hamper the courts' abil-

214 Geier, 529 U.S. at 871-72 (quoting Am. Tel. \& Tel. Co. v. Cent. Office Tel., Inc., 524 U.S. 214, 228 (1998)). This purposive approach to the statutory interpretation of saving clauses is particularly appropriate in situations in which a broadly-interpreted saving clause in federal legislation poses an obstacle to the goals of a separate piece of federal legislation. See, e.g., Donald G. Gifford, William L. Reynolds \& Andrew M. Murad, A Case Study in the Superiority of the Purposive Approach to Statutory Interpretation: Bruesewitz v. Wyeth, 64 S.C. L. REv. 221 (2012); Christopher H. Schroeder, Supreme Court Preemption Doctrine, in Preemption Choice: The Theory, Law, and Reality of Federalism's Core Question 119, 120-21, 135 (William W. Buzbee ed., 2009) (identifying the "crucial question" in preemption analysis as "how to interpret the content of the federal law," which "depends on congressional intent," and comparing preemption cases in which the Supreme Court has relied extensively on legislative history and findings to evaluate congressional intent).

215 See, e.g., Congressional Hearings on the Review of Copyright Law, Copyright .GOV, http://copyright.gov/laws/hearings/ (last visited Apr. 13, 2015). That $\S 301$ (c) does not limit the ability of subsequently-enacted federal copyright provisions to affect state laws governing pre-1972 sound recordings is consistent with the 2011 Copyright Office Report on Federal Copyright Protections for Pre-1972 Sound Recordings, in which the Copyright Office recommended that pre-1972 sound recordings be brought under the federal copyright regime. Copyright Protection for Pre-1972 Sound Re- 


\begin{tabular}{lllll}
\hline |ljciprod01 $\mid$ productn $\backslash \mathrm{C} \backslash \mathrm{CPY} \backslash$ 62-4\CPY402.txt & unknown & Seq: 51 & 29-OCT-15 & 15:26 \\
\hline
\end{tabular}

ity to find conflict preemption under the Supremacy Clause if state laws conflict with federal law as it evolves. ${ }^{216}$

The Supreme Court has also rejected a contention that the presence of an express statutory preemption provision and saving clause "create[s] some kind of 'special burden' beyond that inherent in ordinary pre-emption principles." 217 However, even if the express recognition of states' ability to protect pre-1972 sound recordings in $\S 301(\mathrm{c})$ does require a higher burden in making a case for Supremacy Clause preemption, 218 this burden very likely would be met here. This is not a situation like that noted by the Court in Bonito Boats, where the case for federal preemption is weakened because "Congress has indicated its awareness of the operation of state law in the field of federal interest, and has nonetheless decided to 'stand by both concepts and to tolerate whatever tension there [is] between them." 219 Although Congress was clearly aware of state law protections against unauthorized reproduction and distribution of sound recordings at the time that both the Sound Recording Act of 1971 and the Copyright Act of 1976 were enacted, ${ }^{220}$ the same cannot be said for the

CORDINGS, supra note 6 , at $175-78$. The Report was issued pursuant to the request by Congress that the Copyright Office conduct such a study in the Omnibus Appropriations Act of 2009, H.R. 1105, Pub. L. No. 111-8.

216 Geier, 529 U.S. at 869-74; see also Arizona v. United States, 132 S. Ct. 2492, 2503-04 (2012).

217 Geier, 529 U.S. at 870 (quoting Justice Stevens' dissenting opinion, 529 U.S. at 898-99). Some scholars have criticized the Court's backing away from a presumption against preemption where a saving clause exists, but that criticism is largely focused on regulatory contexts in which state experimentation is encouraged and serves as a complement to the federal regulatory regime. See, e.g., Zeller, supra note 166, at 1668, 1674-79 (criticizing recent Supreme Court cases as failing to apply a presumption against preemption in saving clause cases and stating, "[w] $[\mathrm{w}$ ere Congress includes a savings clause, it recognizes the need either to fill a regulatory void left by federal law or to enhance protection for affected communities through complementary federal and state authorities"). Other scholars have argued that no presumption against preemption exists, but instead that preemption determinations are highly context-specific, requiring "careful application of different interpretive assumptions and substantive principles in specific contexts to determine whether state laws are displaced - in many cases by congressional enactments, but in others by judicial doctrines absent any affirmative action by Congress.” Dinh, supra note 201 at 2087, 2092.

218 See Bonito Boats, Inc. v. Thunder Craft Boats, Inc., 489 U.S. 141, 166-67 (1989).

219 Id. (quoting Silkwood v. Kerr-McGee Corp, 464 U.S. 238, 256 (1984)).

220 See, e.g., S. REP. No. 92-72, at 3-4 (1971) (discussing "widespread unauthorized reproduction of phonograph records and tapes," noting statutes enacted in New York and California to suppress record piracy, but emphasizing the limited relief available under state law in support of the need for federal copyright protection of sound recordings); H.R. REP. No. 92-487, at 2-3 
existence of any state law protection for performance rights in sound recordings. ${ }^{221}$

\section{Let It Be Me:222 Preemption of State Digital Public Performance Rights that Conflict with the Federal Compulsory License}

As discussed in Part II, supra, one of the main purposes of Congress in establishing the compulsory statutory license for digital performances by radio-like services was to create an efficient licensing mechanism for a narrow class of qualifying digital streaming services. ${ }^{223}$ Allowing owners of pre-1972 works to assert state law digital public performance rights directly conflicts with the purposes and objectives of this compulsory license, because it requires digital streaming services that qualify for the federal

(1971) (noting that eight states had enacted statutes protecting against unauthorized reproduction of sound recordings and citing limited nature of remedies available under state law as justification for federal copyright protection of sound recordings); S. REP. No. 104-128, at 10-13 (discussing history of efforts to gain federal protection for sound recordings).

221 See supra Parts I(A) and I(B). Just as the Florida statute in Bonito Boats went beyond any existing state law protections that Congress recognized as being in "tolerable" tension with federal patent law, Bonito Boats, 489 U.S. at 167, here any newly-recognized state law protections for digital performances of sound recordings extend beyond the state law protections for reproduction and distribution rights in sound recordings that existed in 1976 and that Congress had in mind when it added $\S 301(\mathrm{c})$. Thus, $\S 301(\mathrm{c})$ creates no presumption that Congress encouraged enforcement of state laws that actually conflict with subsequent federal copyright policy and objectives regarding digital performance rights in sound recordings.

222 Composed by Gilbert Becaud, Manny Curtis, and Pierre Delanoe; recorded by the Everly Brothers in 1960.

223 The detailed statutory contours of the $\S 114$ digital performance right and the requirements for the statutory license on their face reflect this purpose, setting up a narrow class of transmissions that would qualify for the license and an administrative process for establishing fee structures for the license. The legislative history leading up to enactment of the 1995 DPRA also reflects this purpose. See S. ReP. No. 104-128, at 15-16 (1995); H.R. ReP. No. 104274, at 14 (1995). Within copyright jurisprudence, it is common for the courts to look to the legislative history of the particular provisions of the Copyright Act to aid in interpretation of the statutory language. See, e.g., Am. Broad. Cos., Inc. v. Aereo, Inc., 134 S. Ct. 2498 (2014) (relying heavily on the legislative history of amendments to the Copyright Act that addressed transmissions of audiovisual works to interpret statutory language); Fogerty v. Fantasy, Inc., 510 U.S. 517 (1994) (considering the legislative history of the attorneys' fee provision in 17 U.S.C. $\$ 505$ in determining whether prevailing defendants should be considered differently from prevailing plaintiffs in awarding fees to the prevailing party in copyright infringement cases). 


\begin{tabular}{lllll}
\hline |ljciprod01 $\mid$ productn $\backslash \mathrm{C} \backslash \mathrm{CPY} \backslash$ 62-4\CPY402.txt & unknown & Seq: 53 & 29-OCT-15 & 15:26 \\
\hline
\end{tabular}

compulsory license to separately negotiate licenses with individual owners of pre-1972 sound recordings based on a patchwork of differing state laws, for performances that are not specific to any one state but that are available everywhere that a satellite radio or Internet connection exists. Congress was willing to impose the burden of individual licensing on providers of interactive digital transmissions because those transmissions were most likely to deprive copyright owners of revenues from sales. However, Congress was not willing to impose individual licensing burdens on services that mimicked terrestrial radio, instead creating the compulsory license to reduce transaction costs on services that would be competing with broadcast radio but paying the statutory license for the newly-created public performance right. ${ }^{224}$

Digital public performance rights are thus a narrow category of rights in sound recordings to which individual states cannot claim a localized interest in regulating that could outweigh the federal interest in an efficient licensing mechanism for digital streaming services. Laws governing digital public performance rights are distinct from those addressing the unauthorized physical reproduction of recordings like that analyzed in Goldstein, in part because laws prohibiting physical copying can be limited in their effect to the boundaries of the particular state without unduly impacting the freedom of other states to allow free access to the same works. ${ }^{225}$ No such limitation exists for state laws governing digital streaming; to prohibit a stream in one state means to prohibit it in all states, even those that do not recognize performance rights in sound recordings. ${ }^{226}$ And digital streaming has an even broader reach than the radio broadcasts of sound recordings addressed in Whiteman. ${ }^{227}$ Thus, the problem noted by Judge Hand of limiting the broadcast of recordings to multiple states solely to avoid violation of one state's law 228 would be magnified many times over,

224 See S. Rep. No. 104-128, at 15-16 (1995); H.R. Rep. No. 104-274, at 14 (1995).

225412 U.S. at 558. Although this reasoning could be argued to be inapplicable to digital sales through services like iTunes, an analysis of the local interest in such online activities by individual states is outside of the scope of this article. For a more in-depth discussion of local versus national interests in this context, see Pulsinelli, supra note 175, at 208-17.

226 This is analogous to the concern expressed in Capital Cities Cable, Inc. v. Crisp, 467 U.S. 691, 711 (1984), where cable operators were forced with the choice of either complying with state law but losing the benefits of the compulsory license or refusing to carry programming that was only banned in Oklahoma. In fact, it represents a greater overreaching by the states, in that the cable services at issue in Capital Cities Cable, Inc. were locally-licensed franchises that specifically broadcast to Oklahoma residents, but Internet and satellite radio services are not localized in any one state but are broadcasting everywhere at once.

227114 F.2d at 88 .

228 Id. 
with streaming services forced to comply with the most restrictive state laws despite the fact that their streams reach all jurisdictions simultaneously.

The benefits of a uniform, nation-wide, efficient system envisioned by Congress in specifying services that would qualify for the compulsory license would be nullified if non-interactive, radio-like streaming services were forced to distinguish between individual sound recordings that are streamed over their services to (1) ascertain the date of recording; (2) identify the owner of that recording; (3) identify all performers on the recording who might assert performance rights in it; (4) evaluate whether the laws of any of the fifty-plus states or U.S. territories provide performance rights to the owner and/or performers on the recording; and (5) negotiate a license to stream the particular work for a fee that is acceptable to both the streaming service and the owner/performers. In other words, even when a non-interactive streaming service meets the rigorous requirements for a statutory license under $\S 114$, it would still be required to check millions of sound recordings with tens of millions of owners and performers against fifty-plus state regimes to determine whether any licenses were needed beyond the federal statutory license and whether any payments were required beyond the statutory rate set by the CRJs.

Even those streaming services that have been paying SoundExchange for their streams of pre-1972 sound recordings could still run afoul of state laws, because they have not received individual licenses from pre-1972 sound recording owners and because state laws might be interpreted to require a greater royalty payment than that set by the CRJs. This creates the same sort of administrative obstacle to the federal scheme that was found to be intolerable in Bonito Boats, where the Court noted that the federal patent scheme provided a central location for the public to determine the status of any article in commerce and scope of protection afforded to it and that allowing states to create similar rights in the same products "would lead to administrative problems of no small dimension."229

Moreover, the rate-setting mechanism established by $\S 114$ is designed to accommodate all of the competing concerns involved in noninteractive streaming of sound recordings, establishing fair compensation to rights-holders without overburdening the businesses that stream sound recordings to the public. ${ }^{230}$ Supplementing the statutory license fees es-

229 Bonito Boats, Inc. v. Thunder Craft Boats, Inc., 489 U.S. 141, 161 (1989); see also Greier, 529 U.S. at 881 (discussing importance of predictability and uniformity in a nation-wide standard of care).

230 See, e.g., 17 U.S.C. § 801(b)(1) (2012); see also In re Digital Performance Right in Sound Recordings and Ephemeral Recordings, Copyright Royalty 


\begin{tabular}{lllll}
\hline |ljciprod01 $\mid$ productn $\backslash \mathrm{C} \backslash \mathrm{CPY} \backslash$ 62-4\CPY402.txt & unknown & Seq: 55 & 29-OCT-15 & 15:26 \\
\hline
\end{tabular}

tablished by the CRJs with obligations under state laws would upset the balance inherent in the fee-determination process set up by Congress. ${ }^{231}$

In sum, state law protection of digital performance rights in pre-1972 sound recordings presents an intolerable conflict with the goals of the federal compulsory licensing system established for digital streaming by radio-like services in the DPRA and thus is subject to preemption under the Supremacy Clause. The result of such preemption is that owners of pre1972 sound recordings should be prohibited from relying on state law to enjoin the use of their recordings by digital streaming services that qualify for the federal compulsory license or to seek compensation under state law for such uses.

\section{RESPECT:232 FAIRNESS CONCERNS ABOUT PREEMPTION}

There are many good arguments for extending federal copyright protection to pre-1972 sound recordings. 233 There are also good arguments for limiting or refraining from extending such protection. ${ }^{234}$ This article does not enter into that thorny and policy-laden debate; it merely asserts that state laws purporting to provide protections to pre-1972 sound recordings that interfere with the carefully-balanced compulsory license for certain categories of digital performances of sound recordings should be preempted under the Supremacy Clause.

Several countervailing policy concerns must be taken into account in considering the argument that owners of pre-1972 recordings should be deprived of state law protections for non-interactive digital public performances of their works: expectation concerns, fairness concerns, and

Board, No. 2009-1 CRB, Webcasting III, Final Determination of Rates and Terms (Jan. 5, 2011, effective Mar. 9, 2011).

231 Cf. Crosby v. Nat'l Foreign Trade Council, 530 U.S. 363, 373 (2000) (preempting Massachusetts law preventing use of state funds to support companies that did business with Myanmar because existing federal sanctions against Myanmar were intended to remain within a specific range and state supplementation of the federal sanctions would frustrate the goals of the federal legislation).

232 Composed by Otis Redding; recorded by Aretha Franklin in 1967.

233 See, e.g., Copyright Protection for Pre-1972 Sound Recordings, supra note 6 at 121; Henry Lee Mann, As Our Heritage Crumbles into Dust: The Threat of State Law Protection for Pre-1972 Sound Recordings, 6 WAKE Forest Intell. Prop. L.J. 45 (2006); Eva E. Subotnik \& June M. Besek, Constitutional Obstacles? Reconsidering Copyright Protection for Pre-1972 Sound Recordings, 37 Colum. J.L. \& ArTs 327, 330-42 (2014); Elizabeth Townsend Gard \& Erin Anapol, Federalizing Pre-1972 Sound Recordings: An Analysis of the Current Debate, 15 Tul. J. Tech. \& Intell. Prop. 123 (2012).

234 See, e.g., Subotnik \& Besek, supra note 233, at 343-67; Pulsinelli, supra note 175 , at $240-51$. 
\begin{tabular}{lllll}
\hline |ljciprod01 $\mid$ productn $\backslash \mathrm{C} \backslash \mathrm{CPY} \backslash$ 62-4\CPY402.txt & unknown & Seq: 56 & 29-OCT-15 & 15:26 \\
\hline
\end{tabular}

scope concerns. Although the fairness concerns are particularly powerful, none of these concerns outweighs the very real and substantial interference in the complex DPRA compulsory licensing regime that would be caused by enforcement of state laws protecting digital performance rights.

First, preemption might create expectation concerns. Owners of pre1972 works might have purchased or assigned rights based on anticipated revenue streams from exploitation of a state law digital public performance right, and preemption could interfere with those expected revenues. However, given the lack of any express recognition of a state law digital performance right before the recent 2014 decisions in the Flo \& Eddie litigation, ${ }^{235}$ it cannot be said that those expectations were either longstanding or certain or that they outweigh the strong federal interest in an efficient and comprehensive compulsory licensing system for digital performances by radio-like services.

Second, preemption would create fairness concerns. Royalties from Internet and satellite radio are the only growing revenue stream for owners of sound recordings within the music industry, ${ }^{236}$ and given the lack of federal protection for pre-1972 sound recordings, preemption of state law digital performance rights would preclude owners of pre-1972 sound recordings from participating in at least part of that revenue stream. In an industry where streaming revenues earned by labels and recording artists are close to surpassing revenues from digital downloads and have already surpassed revenues from physical sales of records, ${ }^{237}$ state laws protecting the reproduction and distribution rights in pre-1972 recordings will be of decreasing value to owners of those works over time.

However, the substitution concerns that led Congress to create the digital public performance right in the first place - i.e., that sales of recordings were being replaced by online digital access to sound recordings - are perhaps less weighty in the context of older sound recordings for which the owners had many decades in which to sell copies before the digital revolution began to chisel away the market for sales of records. All of these works are already in their fifth decade or more of existence and presumably benefited from the "golden era" in the recording industry when revenues were far greater than they are for artists producing record-

235 See supra discussion in Part II.

236 See note 74 , infra.

237 See, e.g., Matthew Garrahan, U.S. Streaming Revenues Overtake CD Sales, CNBC.cOM, (Mar. 18, 2015), http://www.cnbc.com/2015/03/18/us-streamingrevenues-overtake-cd-sales.html (noting that RIAA reports showed 2014 streaming revenues surpassed physical CD sales and were approaching revenues from digital downloads). 


\begin{tabular}{lllll}
\hline |ljciprod01 $\mid$ productn $\backslash \mathrm{C} \backslash \mathrm{CPY} \backslash$ 62-4\CPY402.txt & unknown & Seq: 57 & 29-OCT-15 & 15:26 \\
\hline
\end{tabular}

ings today. 238 The copyright monopoly under both state and federal law has always been limited, both in time and scope. Excluding owners of pre1972 recordings from the non-interactive digital transmission revenue stream is not as inequitable as it might seem at first glance when viewed through a longitudinal lens, because newer artists who receive federal protection for their recordings are operating in a market where the pie of total revenues is getting progressively smaller, whereas the owners of older recordings benefited from a growing market during the decades after those works were released.

Third, preemption of state law digital public performance rights in non-interactive digital audio transmissions might raise scope concerns. Owners and potential licensees of pre-1972 sound recordings might be left uncertain as to the degree to which other types of performance rights in pre-1972 works might be affected. However, the argument for preemption made here is a narrow one. The federal compulsory license system in place for digital public performances of sound recordings does not encompass the full range of digital uses of sound recordings. It only applies to a narrowly-defined set of transmissions that generally apply to Internet and satellite radio, and all other uses require individual licenses. ${ }^{239}$ Enforcement of state law digital public performance rights by owners of pre-1972 sound recordings in the context of interactive streaming services like Spotify is unlikely to be preempted, given that the 1995 DPRA already anticipates individual licensing negotiations on a recording-by-recording basis. Requiring additional licenses for pre-1972 recordings under state law would be a relatively small increase in the total burden for interactive services seeking to obtain licenses from sound recording owners. ${ }^{240}$ Thus, those services that meet the strict, narrow requirements of the statutory license will be protected from state law claims by owners of pre-1972 sound recordings under the conflict preemption analysis undertaken here. On-demand services will be left to individual negotiations with sound recording owners for rights to the content, which would not pose the same interference with the federal licensing scheme that is presented when services that do qualify for the statutory license are also required to comply with a myriad of state laws or risk litigation. ${ }^{241}$

238 See, e.g., Andrea Swensen, Forty Years of Music Sales Data in Two Handy Charts, The Current Blog (Feb. 20, 2014), http://blog.thecurrent.org/ 2014/02/40-years-of-album-sales-data-in-one-handy-chart (illustrating increasing revenues from record sales over the period from 1973-1999, with a subsequent decline every year since 1999).

239 See Part III supra, particularly notes 112-114, 116-126, and accompanying text.

240 See 17 U.S.C. $§ 114(d)(2)(A)(i)$ (2012).

241 Supremacy Clause preemption of state laws that are inconsistent with the compulsory licensing provisions of $\S 114(\mathrm{~d})(2)$ would also not run afoul of the general canon of statutory interpretation that one section of a statute can- 
Similarly, preemption of state law digital public performance rights that conflict with the federal compulsory licensing system would have no impact on state laws protecting pre-1972 sound recordings against unauthorized reproduction and distribution, digital or otherwise, other than ephemeral and other reproductions necessary to facilitate the digital public performance right. ${ }^{242}$ Unless and until Congress implements a comprehensive compulsory licensing scheme that affects other state laws protecting rights in pre-1972 sound recordings, the rationale for conflict preemption discussed above would be narrowly confined to the use of sound recordings in non-interactive digital transmissions that qualify for the $\S 114(\mathrm{~d})(2)$ compulsory license. ${ }^{243}$

Ultimately, though, all of the above concerns arise not out of the preemption of state rights that are directly in conflict with federal copyright law, but out of Congress' original decision in 1971, reaffirmed in the Copyright Act of 1976, to exclude pre-1972 sound recordings from federal protection. Inequities resulting from the disparity in treatment between pre1972 and post-1972 recordings were an inevitable result of that original decision, but the growing dominance of digital streaming in the music in-

not be interpreted in a way that effectively repeals another section of the statute. See Tennessee Valley Auth. v. Hill, 437 U.S. 153, 189 (1978). Finding state laws preempted only so far as they conflict with the compulsory license for digital audio streaming would not repeal $\S 301(\mathrm{c})$ as a result of the $\S 114$ compulsory license provision; $\S 301$ (c) would remain fully effective as to any and all state laws that do not fundamentally conflict with the goals and purposes of specific provisions of the federal copyright act.

242 See 17 U.S.C. $\$ 112$ (2012) (establishing narrow statutory license for ephemeral recordings arising out of digital streaming under a $\$ 114$ statutory license). This article presumes, without analyzing in depth, that the same rationale for conflict preemption of state law performance right claims that applies to digital streaming under a $\S 114$ statutory license would apply to claims based on state law arising out of ephemeral copying covered under the $\S 112$ license.

243 The rationale for preemption of state law rights affecting transmissions that qualify for the statutory license under $\S 114(d)(2)$ might also support preemption of state law rights affecting transmissions that are exempt from any licensing under $\S 114(\mathrm{~d})(1)$. Just as the language and history of the patent laws demonstrated an express intent by Congress to leave some categories of works that might be subject to the patent monopoly free for the public to use that justified preemption of conflicting state laws in Sears and Compco, see supra notes $157-163$ and accompanying text, $\S 114$ 's creation of categories of digital public performances that are exempt from any licensing could be found to demonstrate an express intent by Congress to leave those types of uses free for public use. Because preemption analysis requires careful consideration of the particular statutory provisions at issue and the potential conflict created by state laws, and because no state laws have yet been asserted that would impose liability on exempt transmissions under $\S 114$, a full analysis of that question is outside the scope of this article. 


\begin{tabular}{lllll}
\hline |ljciprod01 $\mid$ productn $\backslash \mathrm{C} \backslash \mathrm{CPY} \backslash$ 62-4\CPY402.txt & unknown & Seq: 59 & 29-OCT-15 & 15:26 \\
\hline
\end{tabular}

dustry has exacerbated those inequities. It is thus not surprising that both owners of pre-1972 sound recordings and individual states have been seeking ways to ensure that legacy works are included in this growing revenue stream. However, remedies based solely upon state law would be inconsistent, perhaps contradictory, and incompatible with the objectives of the federal statutory license. These concerns can and should all be addressed by Congress, in a context in which it can carefully consider and balance the competing interests already reflected in the 1995 DPRA, as well as the equitable concerns regarding compensation to owners of pre-1972 sound recordings (and to the artists who created them), the expectations of those who might have licensed those works, and the scope of protection that might be provided to those works.

In fact, over the past several years, bills have been introduced in Congress to address these issues and the Copyright Office has engaged in a detailed study of the issues raised by possible federal protection of pre1972 sound recordings. ${ }^{244}$ Last year, Congress introduced H.R. 4772, known as the "RESPECT Act," which would have brought pre-1972 sound recordings within the ambit of the $\S \$ 114$ and 112 compulsory licenses for purposes of compensation without providing federal copyright protection to those works, immunizing any digital streaming services that paid the statutory license fee from any state law claims based on the use of the sound recordings. ${ }^{245}$ Similar provisions were incorporated into the recently introduced Fair Pay, Fair Play Act of 2015, which provides that its objective is "to provide fair treatment of radio stations and artists for the use of sound recordings." 246 Although the Fair Pay, Fair Play Act focuses

244 See, e.g., H.R. 4772 (113th Cong. 2014); Copyright And the Music MarketPLACE, supra note 5. The February 2015 Copyright Office Report on Copyright and the Music Marketplace expressly recommended that pre-1972 sound recordings be brought under federal copyright protection, noting, "The lack of federal protection for pre-1972 sound recordings impedes a fair marketplace. Record labels and artists are not paid for performances of these works by digital services, which (at least until recent court rulings under state law) were considered free from copyright liability on the sound recording side." COPYRIGHT AND THE Music MARKeTPlace, supra note 5, Executive Summary at 3.

245 Respecting Senior Performers as Essential Cultural Treasures Act, H.R. 4772, 113th Cong. (2014).

246 H.R. 1733, 114th Cong. (2015). This bill is reminiscent of the 1909 Copyright Act's attempt to deal with composer's rights in mechanical reproductions of compositions by providing for a statutory license without providing copyright protection to the particular recording of the composition. See 17 U.S.C. § 1(e) (1909); Goldstein, 412 U.S. at 563-66. Some argue that it does not go far enough, but it would provide some recompense to owners of pre1972 sound recordings for digital radio streams of their works without having to wrestle with the more difficult questions about bringing previously 
\begin{tabular}{lllll}
\hline |ljciprod01 $\mid$ productn $\backslash \mathrm{C} \backslash \mathrm{CPY} \backslash$ 62-4\CPY402.txt & unknown & Seq: 60 & 29-OCT-15 & 15:26 \\
\hline
\end{tabular}

604 Journal, Copyright Society of the U.S.A.

primarily on parity among different radio station platforms (including terrestrial radio, webcasting, satellite radio, and personalized streaming radio stations), section 7 would require digital audio transmission services that qualify for the statutory license to pay owners and creators of pre-1972 recordings in the same manner as they do post-1972 recordings. ${ }^{247}$ It would also immunize services that make those payments from liability under any state laws that might be claimed to protect public performance rights in pre-1972 recordings, but it expressly refrains from providing federal copyright protection to those works. 248

One possible remedy at the state level might be adoption of a uniform state law that requires digital audio transmission services that qualify for the $\S 114$ statutory license to pay for performances of pre-1972 sound recordings in the same manner that federal law requires for performances of post-1972 sound recordings - essentially the mirror image of the Fair Pay, Fair Play Act's provision of immunity against state law liability for performances of pre-1972 recordings if the statutory license fee is paid by services that qualify for it. Certainly, the adoption by such a law by a majority of states would avoid some of the conflict justifying preemption discussed in Part III(B), supra. Some conflict with the federal licensing scheme would still exist, because streaming services would still carry the additional burden, beyond compliance with the federal statutory license, of having to determine which pre-1972 recordings are protected by which state laws. That problem could potentially be addressed by provisions in the uniform state law that would require owners of pre-1972 recordings to register their works in a way that provides notice to streaming services of a claim to the protection of a particular state's laws for those recordings. There still, however, would be a question as to whether requiring a qualifying service to do any more than the federal statutory license requires would create an obstacle to the proper functioning of the $\S 114$ license. And the rate-setting process could be undermined even with a uniform state law, because the effect of such state laws on the total license fees to be paid by individual services would be hard for the CRJs to measure and factor into the balance of interests unless and until all fifty states had enacted those laws.

The most effective solution for addressing fairness and scope concerns in a way that does not interfere with the objectives of the $\S 114$ statutory licensing regime is for Congress to act. Passage of the provisions of the Fair Pay, Fair Play Act of 2015 relating to digital performances of pre-1972 sound recordings could provide an effective remedy for the concerns dis-

unprotected works under the umbrella of federal protection that are outside the scope of this article.

247 Id. $\S 7(\mathrm{a})$.

248 Id. 


\begin{tabular}{lllll}
\hline |ljciprod01 $\mid$ productn $\backslash \mathrm{C} \backslash \mathrm{CPY} \backslash$ 62-4\CPY402.txt & unknown & Seq: 61 & 29-OCT-15 & 15:26 \\
\hline
\end{tabular}

cussed above that were created by the congressional decision to protect only post-1972 recordings and that could be exacerbated by preemption of state laws governing digital public performances. In fact, a judicial finding of Supremacy Clause preemption of such state law claims might spur Congress to act more expeditiously in dealing with the problem it created when it exempted pre-1972 sound recordings from federal copyright. Rather than leaving individual state courts or legislatures to fashion remedies that hinder the goals of the compulsory licensing system for digital public performances of sound recordings, Congress should address the competing arguments and whether they merit amendments to the carefully balanced compulsory licensing system adopted in 1995 .

\section{AT LAST ${ }^{249}-$ CONCLUSION}

Nothing in this article is intended to minimize the cultural and artistic importance of sound recordings that were made before 1972. However, Supremacy Clause preemption of just the narrow category of digital public performance rights addressed in this article - digital streams that meet the requirements for the limited compulsory license under $\S 114-$ does not leave owners of pre-1972 sound recordings without any protection. They may still protect their works under state law against illegal reproduction and distribution, including unlicensed digital downloads. State laws protecting interactive digital audio transmissions are also unlikely to be preempted given Congress' willingness to allow individual licensing for those uses of sound recordings.

So long as pre-1972 recordings receive no federal copyright protection and are excluded from the federal compulsory licensing regime, efforts by individual states to provide compensation to those artists and their record labels for non-interactive digital performances of their works will likely pose too great a conflict with the federal statutory license regime to be permitted. State-by-state litigation and legislation not only interferes with the goals of the federal statutory license, but it also risks harm to all artists and to the listening public if non-interactive streaming services are overburdened and opt to eliminate access to these works or are unable to sustain their services. Supremacy Clause preemption alone would be sufficient to keep the well-loved recordings of Frank Sinatra, Elvis Presley, Etta James, and hundreds of other recording artists whose records were made before February 15, 1972, available to the public through Internet and satellite radio services, but it would leave the owners and performers

249 Composed by Mack Gordon and Harry Warren in 1941, At Last was recorded by Etta James in 1961, and her recording of the song was inducted into the Grammy Hall of Fame in 1999. Grammy Hall of Fame, Grammy.org, http://www.grammy.org/recording-academy/awards/hall-of-fame (last visited Mar. 19, 2015). 
of those works uncompensated for those performances. The question of whether and how compensation might be provided for radio-like streaming of pre-1972 sound recordings should thus be addressed by Congress. In evaluating that question, Congress should of course take into consideration the competing interests that it balanced in enacting the 1995 DPRA and in crafting the statutory license. However, it should also consider the rising popularity of streaming as a substitute for sales of music and the economic effect of precluding the owners and performers of pre-1972 sound recordings from this revenue stream, recognizing the importance of many of these works to our nation's cultural heritage. 